Review

\title{
Biomass Waste as Sustainable Raw Material for Energy and Fuels
}

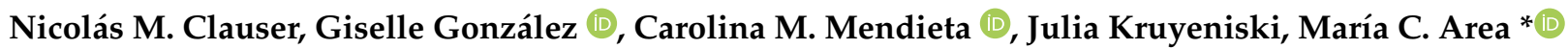 \\ and María E. Vallejos
}

Citation: Clauser, N.M.; González, G.; Mendieta, C.M.; Kruyeniski, J.; Area, M.C.; Vallejos, M.E. Biomass Waste as Sustainable Raw Material for Energy and Fuels. Sustainability 2021, 13, 794. https://doi.org/ $10.3390 /$ su13020794

Received: 20 December 2020 Accepted: 13 January 2021 Published: 15 January 2021

Publisher's Note: MDPI stays neutral with regard to jurisdictional clai$\mathrm{ms}$ in published maps and institutional affiliations.

Copyright: (C) 2021 by the authors. Licensee MDPI, Basel, Switzerland. This article is an open access article distributed under the terms and conditions of the Creative Commons Attribution (CC BY) license (https:// creativecommons.org/licenses/by/ $4.0 /)$.
IMAM, UNaM, CONICET, FCEQYN, Programa de Celulosa y Papel (PROCyP), Félix de Azara 1552, Posadas 3300, Argentina; nicolas.clauser@gmail.com (N.M.C.); gi.gonzalez.93@gmail.com (G.G.); caroo.mendieta@gmail.com (C.M.M.); kruyeniskijulia@gmail.com (J.K.); mariaxvallejos@gmail.com (M.E.V.)

* Correspondence: cristinaarea@gmail.com; Tel.: +54-376-4422198

\begin{abstract}
Sustainable development is the common goal of the current concepts of bioeconomy and circular economy. In this sense, the biorefineries platforms are a strategic factor to increase the bioeconomy in the economic balance. The incorporation of renewable sources to produce fuels, chemicals, and energy, includes sustainability, reduction of greenhouse gases (GHG), and creating more manufacturing jobs fostering the advancement of regional and social systems by implementing the comprehensive use of available biomass, due to its low costs and high availability. This paper describes the emerging biorefinery strategies to produce fuels (bio-ethanol and $\gamma$-valerolactone) and energy (pellets and steam), compared with the currently established biorefineries designed for fuels, pellets, and steam. The focus is on the state of the art of biofuels and energy production and environmental factors, as well as a discussion about the main conversion technologies, production strategies, and barriers. Through the implementation of biorefineries platforms and the evaluation of low environmental impact technologies and processes, new sustainable production strategies for biofuels and energy can be established, making these biobased industries into more competitive alternatives, and improving the economy of the current value chains.
\end{abstract}

Keywords: biomass; lignocellulosic wastes; sustainable feedstocks; bioenergy; biofuels

\section{Introduction}

Currently, fossil fuel consumption is the principal cause of global warming and pollution. Oil reserves are neither renewable nor available worldwide; hence, renewable energy's replacement is critical to reducing crude oil dependence. In this context, these environmental and economic consequences led to developing renewable energy alternatives (biofuels, hydrogen, wind, solar, and bioenergy), taking into attention sustainability and techno-economic feasibility [1]. Transportation and processing of fossil resources lead to economic, political, and environmental issues that could be solved by the biorefineries, which are similar to conventional ones but uses biomass as feedstock, the chief renewable resource of carbon in the world. In the context of the COVID-19 pandemic, the International Energy Agency (IEA) estimated that 2020 primary energy demand could decline for oil by $-9 \%$, coal by $-8 \%$, and natural gas by $-2 \%$. However, renewable energies are expected to increase due to preferential access, the recent growth in capacity, and project start-up [2].

Bioenergy can be generated from the biomass as heat, power, or biofuels (solid, liquid, or gaseous) by thermochemical or biochemical processes (Figure 1). Direct burning of biomass is feasible, although a low-value option. $\mathrm{CO}_{2}$ in the air, water, and sunlight by photosynthesis reactions, to produce carbohydrates, form the building blocks of biomass. Carbon dioxide produced by burning biomass is balanced by replanting, so it is again absorbed and returned for a new growth cycle. 


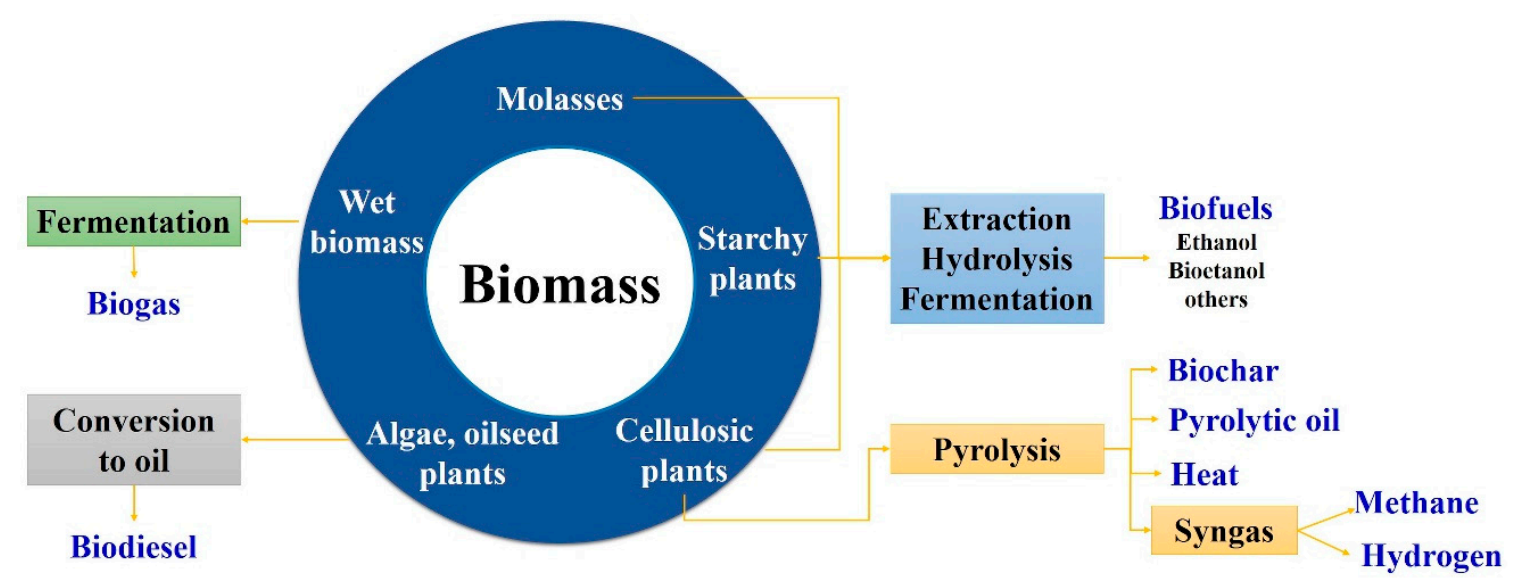

Figure 1. Different types of biofuel products from lignocellulosic biomass.

Biofuels are a potential alternative in the transport sector because they can be produced anywhere in the world where biomass is available, ensuring an energy supply environmentally friendly, which contributes to the sustainability and development of forest-agriculture and its related industries [3]. Latin America has an enormous potential to produce biofuels because of the climatic conditions and spacious areas suitable for forestry and agriculture. In Brazil, around 50\% of cultivated sugarcane is used for biofuel production (from 4.4 Mha in 2008 to 8 Mha in 2017). Currently, liquid biofuels are about $3 \%$ of the global transport energy, but the market size could grow significantly up to $27 \%$ by 2050 [4].

Liquid biofuels are classified based on the type of biomass used for their production, in first- $(1 G)$, second-( $2 G)$, and third-generation (3G). First-generation biofuels are produced from edible biomass rich in sugars, starches, and (or) fats. Since there is a continuous growth in the human population, this biomass should be used for feeding to guarantee compliance with human rights. Third-generation biofuels are produced from aquatic biomass (algae and cyanobacteria). Second-generation biofuels involve lignocellulosic biomass (LCB) or non-edible waste from first-generation biomass. However, they entail challenges since this kind of biomass comprises a complex matrix of three principal components (namely cellulose, hemicelluloses, and lignin) that must be deconstructed to achieve products with acceptable yields. 2G biofuels require lower land, water, and nutrient than $1 \mathrm{G}$ and $3 \mathrm{G}$ ones; they do not compete with food, and their commercialization and production costs allow large-scale biofuel production. The $1 \mathrm{G}$ ethanol production cost is between 0.78 and $0.97 \mathrm{USD} / \mathrm{L}$. The production cost of $2 \mathrm{G}$ biofuels lies between $1 \mathrm{G}$ and $3 \mathrm{G}$ ones, but 3G ethanol production is at pilot scale. Brazil produces the cheapest $1 \mathrm{G}$ ethanol due to the combination of readily available resources and cheap labor, making possible prices of about 0.20 USD/L [1].

Lignocellulose wastes are considered an ideal biomass feedstock for sustainable biofuel production, are a low-cost resource, and abundantly available in some regions like Latin America and Asia. They are a common problem, and various environmental policies are being taken to manage biomass waste generated from diverse sources (agricultural, forest, wood industrialization, and municipal pruning). The possibility to valorize the amounts of lignocellulosic forest wastes are developing rapidly. The interest of the chemical industry in renewable feedstocks is growing significantly, particularly in developing economies where the demand for biofuels and chemical products is increasing, and the lignocellulosic wastes are more available than in developed economies. The value of a particular type of biomass depends on the chemical and physical properties of its constituents. Local biomass wastes as feedstocks could reduce the importation of petroleum oils and their dependence, which could favor the marketability, employment opportunities, and rural development in emerging economies [5]. It is expected that, in 2030, 20\% of transportation fuels and $25 \%$ of chemicals will be produced from LCB [6]. 
The economic competitiveness can be determined by a technical-economical assessment, which allows knowing the key indicators, like cost, benefit, and investment values. The potential environmental hazards of biofuel production in a biorefinery should be minimized without significantly affecting the economic sustainability. Some useful tools in this regard are the systematic analysis of the inputs and outputs based on the mass and energy balances, the environmental impacts attributable to the biofuels production by life cycle assessment (LCA), and other efficient methodologies like evaluation impact, waste generation, environmental risk, and atmospheric hazards index, among others. Social sustainability assessment can be determined by analyzing, mainly, energy and food security (price fluctuation), employment generation, human exposure risk (health), and others.

The biorefinery concept is being applied worldwide in various industrial sectors (energy, transport, food, chemical, health, pharmaceutical, others), and its principal challenge is to reach socio, economic, and environmental sustainability and maintain it in the future (Figure 2) [7]. There are different processing routes for the production of biofuels from biomass. Biorefineries are mainly classified into the syngas or thermochemical and the sugars platforms. This last one involves biochemical conversion processes that focus on the fermentation of sugars extracted from biomass [8]. Economically sustainable biofuel production by biochemical means is determined by a suitable combination of substrate, pre-treatment, biocatalyst (or microorganism capability), product manufacture, recovery and (or) recycling, and commercialization.

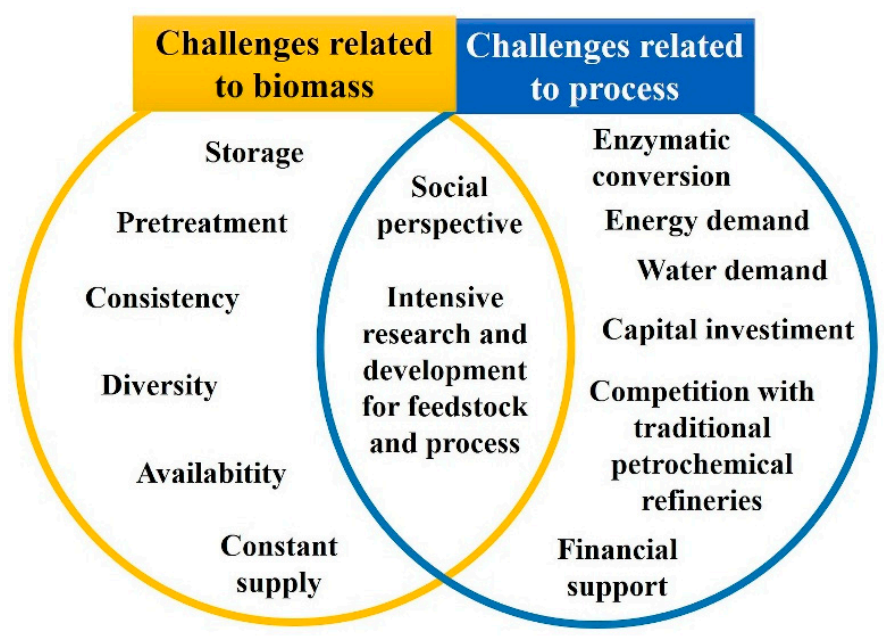

Figure 2. Main challenges for biofuel production in biorefineries.

In thermochemical platforms, gasification or liquefaction (depending on the concentration of oxygen and the heating ramp to which the feedstock is subjected) can generate different products such as bio-oil (together with char and gases), a more oxygenated and functionalized product compared to its crude oil counterpart (see Figure 3). These products can be subsequently upgraded (by hydrodeoxygenation, cracking, hydrocracking, or steam reforming), thus generating transportation fuels comparable to conventional ones [9]. The advantages of biofuels production by thermochemical processes lie in the closed carbon balance and the lower concentrations of sulfur and nitrogen compounds present in the fuel, which decrease $\mathrm{SO}_{x}$ and $\mathrm{NO}_{x}$ emissions. A disadvantage of this method for biofuel production from biomass using heterogeneous catalytic processes is its oxygen content since this feed is more prone to the generation of coke on the catalyst, leading to deactivation. Besides, the presence of water-soluble compounds requires that the reactions take place in the aqueous or alcoholic phase. 


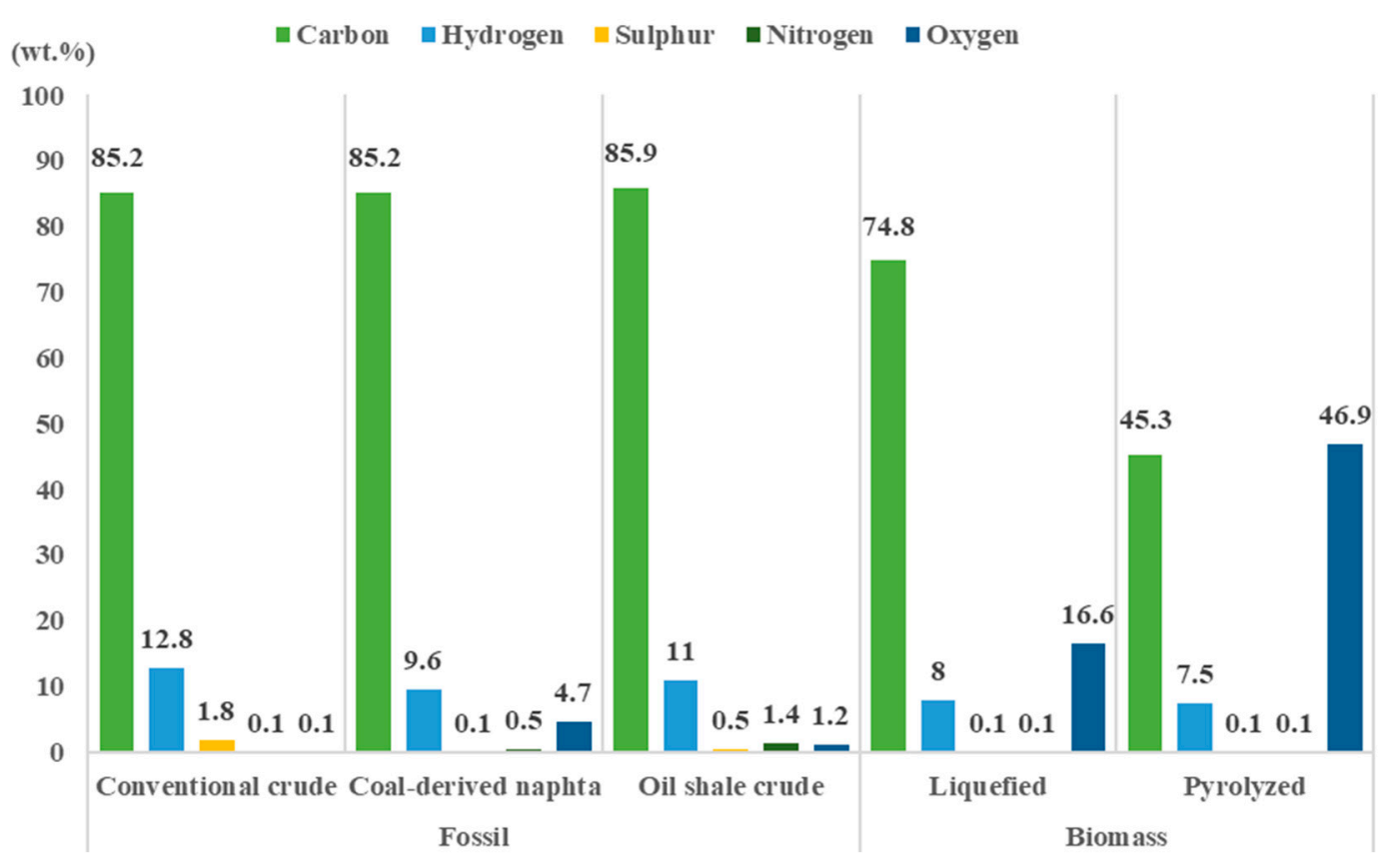

Figure 3. Composition of different feeds for hydrodeoxygenation [10].

Several challenges encompass technology and economics to achieve acceptable yields and product costs to compete with fossil products. Partial replacements can be implemented within petrochemical processes while obtaining biomass products is investigated and optimized. For example, bio-oil could be co-processed with conventional crude oil in fluid catalytic cracking (FCC) processes to obtain hydrocarbons. In this way, less oxygenated hydrocarbons are produced than in a pure bio-oil stream, but more coke is generated than conventional crude oil FCC. However, this amount would be less than expected from a pure bio-oil due to a synergy of the hydrogen contribution from fossil oil [11]. Nowadays, conventional oil and chemicals companies such as Shell [12] and Exxon [13], among others, are already developing processes and technologies for the production of biofuels and biochemicals. At this moment, these industries' efforts in collaboration with researchers and pilot plants are focused mainly on bioethanol as fuel for its use in mixtures with gasoline [14].

This review deals with the implementation of biorefineries to produce liquid biofuels and energy from solid lignocellulosic waste. Bioethanol, $\gamma$-valerolactone, pellets, and steam are shown as case studies. Sustainability challenges are mentioned, and alternatives are proposed.

\section{Bio-Ethanol and $\gamma$-Valerolactone as Cases Study of Sustainable Fuels}

\subsection{Processes for $1 G$ and $2 G$ Bio-Ethanol Production}

The global interest in the use and production of biofuels to replace fossil fuels has grown significantly in the last decade [15] due to the cost and negative impact on the environment of these last ones [16]. 2G bio-ethanol reduces GHG emissions and favors the use of low costs and highly available industrial waste [17]. Biomass, similar to oil, has a complex chemical composition based on carbon chains, which can be separated into intermediate molecules and processed to obtain high-value products [18]. Green ethanol, a currently used biofuel, is environmentally friendly and leads to energy savings. However, since it requires a time-intensive biological process, time reduction is the focus of new research $[19,20]$. The use of a gasoline-ethanol blend as an alternative motor fuel has steadily increased over the years [21]. National production and use of ethanol as fuel can decrease dependence on foreign oil, reduce trade deficits, create jobs in rural areas, and reduce air pollution together with carbon dioxide build-up from global climate change. Unlike gasoline, ethanol is an oxygenated fuel that contains 35\% oxygen, which reduces 
particulate and NOx emissions from combustion [22]. Bioethanol obtained from the sugar platform can be classified into first generation (1G), second-generation $(2 \mathrm{G})$, and thirdgeneration (3G) bioethanol (in this section, we will focus on the production of $1 \mathrm{G}$ and $2 \mathrm{G}$ ), as can be seen in Table 1 .

Table 1. Characteristics of the first generation (1G), second-generation (2G), and third-generation (3G) bioethanol production.

\begin{tabular}{|c|c|c|c|}
\hline & 1G & $2 \mathrm{G}$ & $3 G$ \\
\hline Raw material & $\begin{array}{l}\text { Crops (soybean oil, corn } \\
\text { starch, or sugar cane). }\end{array}$ & $\begin{array}{l}\text { Lignocellulosic biomass (different } \\
\text { varieties of wood, bagasse, or } \\
\text { straw of sugarcane) }\end{array}$ & Algae (microalgae or macroalgae) \\
\hline Process & $\begin{array}{l}\text { Extraction Enzymatic } \\
\text { hydrolysis Fermentation }\end{array}$ & $\begin{array}{l}\text { Pretreatment Acid or enzymatic } \\
\text { hydrolysis Fermentation }\end{array}$ & $\begin{array}{c}\text { Acid or enzymatic hydrolysis } \\
\text { Fermentation }\end{array}$ \\
\hline Advantages & $\begin{array}{l}\text { The simplicity of the process } \\
\text { (already available) }\end{array}$ & Does not compete with food. & $\begin{array}{ll}\text { - } & \text { Ease of availability } \\
\text { - } & \text { Does not compete with food } \\
\text { - } & \text { Eventually has a much lesser } \\
\text { impact on the environment } \\
\text { - } \quad \text { Low lignin content }\end{array}$ \\
\hline Main disadvantages & $\begin{array}{l}\text { The debate of competition } \\
\text { with food }\end{array}$ & The recalcitrance of raw material & Up-scaling in development \\
\hline
\end{tabular}

$1 \mathrm{G}$ bioethanol is generated from the hydrolysis of carbohydrates and subsequent enzymatic fermentation of sugars. It is the most produced biofuel in contemporary biorefineries because its process is well-known, and the procedures have been refined through the years [23]. The mechanism to obtain $2 \mathrm{G}$ bioethanol includes a pretreatment, enzymatic saccharification, and fermentation [20]. On the one hand, pretreatment facilitates the fractionation of the biomass and improves the subsequent enzymatic hydrolysis yield [24], in which different enzymes act to cause the breakdown of cellulose polymers to glucose monomers [25]. Subsequently, fermentation is carried out using a yeast (generally Saccharomyces cerevisiae) to produce bioethanol [26].

Currently, the usual strategies for bioethanol production are separate hydrolysis and fermentation (SHF) and simultaneous hydrolysis and fermentation (SSF) [27]. In the first one, both stages are carried out separately, with the advantage that each stage can be performed in their optimum conditions. However, its disadvantage is the generation of inhibition products, that is, glucose for the hydrolysis and ethanol for the fermentation [28], which limits achieving high concentrations of both sugar and ethanol, and therefore makes the commercialization of lignocellulosic ethanol more expensive [29].

On the other hand, hydrolysis and fermentation are carried out in a single reactor in a simultaneous process. Its main advantage relies on the immediate consumption of sugars produced in hydrolysis by yeasts, avoiding the problems of sugar accumulation and bacterial contamination [30]. Besides, the use of a single reactor reduces the cost and makes the process more efficient [31]. SSF was further optimized by incorporating a short pre-saccharification followed by simultaneous saccharification fermentation (pSSF). This alternative provides benefits by supporting high loads of solids, reducing quickly the initial viscosity of the substrate that leads to an increase of ethanol yield [32]. Specifically, the substrate is incubated with hydrolytic enzymes in a short time, generally between 8 and $24 \mathrm{~h}$. Then, the SSF proceeds when the microorganism is inoculated, improving the saccharification process due to the different optimum temperatures of the enzymes $\left(50^{\circ} \mathrm{C}\right)$ and the traditional fermentation yeasts $\left(30^{\circ} \mathrm{C}\right)[33,34]$.

Production of $2 \mathrm{G}$ bioethanol requires additional research and optimization of the involved processes for its development on a large-scale. The implied variables can be seen in Figure 4. 


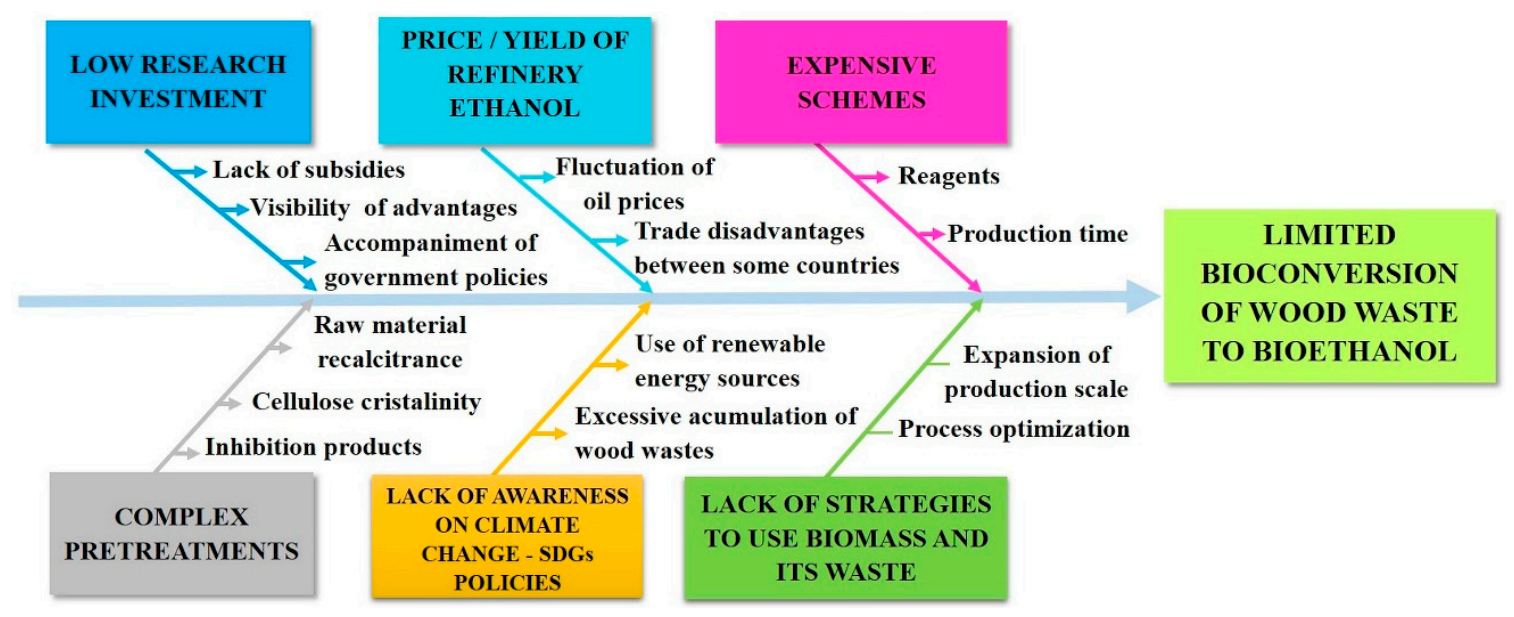

Figure 4. Ishikawa diagram applied to bioethanol development.

Lignocellulosic material hydrolysis is more difficult than that of starch due to its recalcitrant structure [24]. Lignin forms a protective barrier for cellulose microfibrils, making difficult the cellulose hydrolysis to glucose [35]. Furthermore, the link between lignin and hemicelluloses hinders the degradation of these last ones to pentose and hexose sugars [36,37]. For this reason, LCB requires optimal pretreatment to eliminate the highest lignin content from the material and depolymerize the cellulose into simple sugars by saccharification so that the fermentative microorganisms can produce the most significant amount of bioethanol $[17,38]$.

According to the International Renewable Energy Agency (IRENA), bioethanol cost from corn in 2012 was estimated at 0.9-1.1 USD/L of gasoline-equivalent (LGE), and from Brazilian sugarcane at 0.7-0.9 USD/LGE, whereas from lignocellulosic feedstocks it increased to 1.04-1.45 USD/LGE [39]. As a consequence, biorefinery schemes require a lot of effort in terms of stream integration and operation optimization [40]. Setting up a bioethanol production plant involves a considerable investment, in particular, make decisions on raw material, pretreatments, energy costs, scale, yields, among others [41-44]. Hence, the bioproducts have a high price in comparison with the final fossil product [45]. Some countries-like Brazil, India, United States, and China-have bioethanol biorefineries operating at industrial scales. The leading bioethanol producer is Brazil, which employs sugarcane juice as a raw material, which also is used in the food industry [39].

As a raw material for bioethanol production, wood presents complexities like its cellulose crystalline structure, high content of lignin, and fractionation requirement [18]. Besides, softwood wastes contain hydrophobic resin, which possibly affects the feedstock structure and also the fractionation mechanism. Hence, the pretreatment is very demanding and costly [46].

It is necessary to develop a techno-economic assessment for wood waste industries to obtain greater yields and increase marketability. Looking forward to biorefineries development, government policies must accompany this determination with subsidies, qualified labor, visibility of advantages, biofuel mix, among others [47]. Collaboration between various actors, like researchers, government, universities, investors, and society is necessary $[47,48]$. For example, sponsoring of enterprises in scientific or academic events can lead to a synergistic relationship between the public and private sector, in which the problem of one can be solved by the other, and vice versa [49]. Besides, governments can impulse contests and awards for companies that are continuously trying to achieve sustainable development [50]. In that sense, several types of case studies has been carried out: (i) recent trends in the law and policy of bioenergy production, promotion, and use in Latin America, Asia, and Africa was carried out by Food and Agriculture Organization of the United Nations (FAO) [51]; (ii) liquid biofuels production in Africa, Asia, and Latin America by members of the Global Network on Energy for Sustainable Development (GNESD), providing specific case examples and approaches ranging from addressing agro- 
ecological zoning and sustainability indicator issues, to policy design on end-products in biofuel implementation in five selected countries (Brazil, Kenya, Senegal, Argentina, and Thailand) [52]; (iii) technologies to produce liquid biofuels for transportation by the Center for International Forestry Research (CIFOR) [53]; (iv) development of guidelines for decision makers on the biofuels screening toolkit by the Global Environment Facility (GEF), United Nations Environment Programme (UNEP), FAO and United Nations Industrial Development Organization (UNIDO) agencies and several research institutes [54]; and (v) Brazil-EU cooperation for the development of advanced lignocellulosic biofuels (BECOOL) by a consortium of thirteen partners from seven EU countries, including universities, research institutes, industries, and small and medium enterprises (SMEs) [55].

\subsection{Processes for the Production of GVL}

In sugar platforms, the first stage is biomass fractionation for lignin removal. The fraction of carbohydrates can be subsequently hydrolyzed (and isomerized, in the case of glucose to fructose) to obtain hexoses and pentoses (mainly glucose and xylose), which are dehydrated and rehydrated to levulinic acid (LA), which is considered a platform molecule [56]. $\gamma$-valerolactone (GVL) is then obtained by hydrogenation and subsequent dehydration, leading to cyclization [57]. The whole process is catalyzed by acid sites, which can be conferred by homogeneous or preferably heterogeneous catalysts due to their higher selectivity and recyclability [58]. The complete pathway from biomass to GVL can be seen in Figure 5.

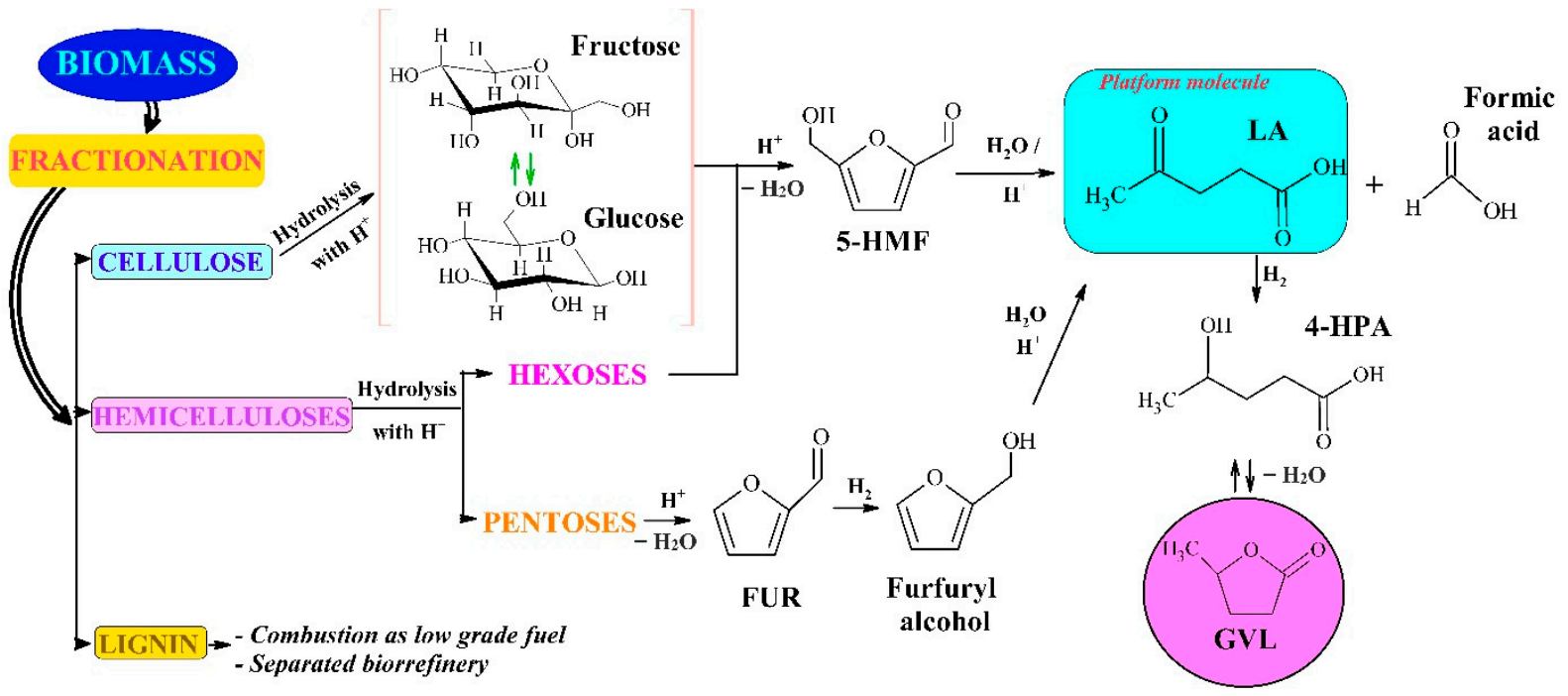

Figure 5. Obtaining of GVL through an acid catalytic processes with molecular hydrogen as the source in the hydrogenation [59-61].

GVL is similar to bioethanol in several properties like water solubility, high oxygen concentration, and low relative energy density compared with their fossil counterparts (see Table 2), for which it cannot be used directly as biofuel. However, it is better used as a fuel additive (oxygenates) in mixes with fossil fuels that vary depending on the country's regulations. In Argentina, the mix of bioethanol in gasoline is set at $12 \%$. The research octane number (RON) for grade 2 (high-grade) has to be between 93 and 95, whereas grade 3 is between 95 and 97 . For Gasoil (diesel fuel), the cetane number is set at 48 for grade 2 and 51 for grade 3, with a $10 \%$ biodiesel mix [62]. GVL has a higher energy content and lower vapor pressure (which leads to lower volatile organic compound emissions in storage), thus could be better than bioethanol when used as a fuel additive $[63,64]$. It has been tested as an oxygenating agent in gasoline (mixtures of $10-30 \% v / v)$ and diesel fuel $(1 \%$ and $2.5 \% v / v$ ), using the advanced distillation curve methodology, leading the distillation curve to lower temperatures for diesel fuel, and higher temperatures for gasoline [64]. The 
evaluation of a mixture of $10 \% v / v$ GVL or EtOH and $90 \% v / v$ 95-octane gasoline shows that both have very similar properties. Moreover, GVL production costs might be lower since it does not form an azeotrope with water as ethanol does, which makes it easier to purify before use [62]. Besides, it was verified that by adding low concentrations of GVL in a mixture of biodiesel and fossil diesel, the performance of power and fuel consumption was similar compared to conventional diesel. Besides, the THC (total hydrocarbon), CO emissions, and smoke concentration of the exhaust gas decreased significantly [65].

Table 2 shows that the cetane number for ethanol and GVL is too low for its direct use as biofuel (compared to diesel and biodiesel). On the other hand, low $\mathrm{H} / \mathrm{C}$ ratios require more processing, higher $\mathrm{H}_{2}$ input, and imply less clean combustion. In fossil feedstocks, lower $\mathrm{H} / \mathrm{C}$ means lower quality. GVL is a keto-lactone with high reactivity conferred by its functional groups. It is a green molecule that has plenty of possible uses, as a precursor for $\mathrm{C} 8, \mathrm{C} 9-\mathrm{C} 18$, or $\mathrm{C} 9$ alkanes and valeric esters, as a green solvent in fine chemistry together with food and fuel additives synthesis, and as intermediate for high-value compounds (such as 1,4-pentanediol or methyl pentanoate) [6]. GVL can be used as a proper solvent to valorize lignin or humic materials to produce high-value chemicals due to the favorable solubility [66]. Organosolv GVL/water systems can lead to an effective fractionation of LCB. In this way, the process could be circularized by the partial recirculation of the product, fulfilling the role of solvent $[67,68]$.

Table 2. Comparison between ethanol, GVL, and diesel fossil and biodiesel $[6,65,69]$.

\begin{tabular}{|c|c|c|c|c|}
\hline Terms & Ethanol & GVL & $\begin{array}{c}\text { Diesel } \\
(2-D)\end{array}$ & $\begin{array}{c}\text { Biodiesel } \\
\text { (FAME) }\end{array}$ \\
\hline $\mathrm{MW}(\mathrm{g} / \mathrm{mol})$ & 46.07 & 100.12 & & \\
\hline Refractive index $\left(40^{\circ} \mathrm{C}\right)$ & 1.3538 & 1.4254 & & \\
\hline Carbon $($ wt \%) & 52.2 & 60 & 87 & 77 \\
\hline Hydrogen (wt \%) & 13.1 & 8 & 13 & 12 \\
\hline Oxygen (wt \%) & 34.7 & 32 & 0 & 11 \\
\hline Boiling point $\left({ }^{\circ} \mathrm{C}\right)$ & 78 & 207 & & \\
\hline Melting point $\left({ }^{\circ} \mathrm{C}\right)$ & -114 & -31 & & \\
\hline Flash point $\left({ }^{\circ} \mathrm{C}\right)$ & 13 & 96 & 66 & $120-130$ \\
\hline Density (g/mL) & 0.789 & 1.05 & 0.82 & $0.86-0.90$ \\
\hline Vapor pressure $(\mathrm{kPa})\left(25^{\circ} \mathrm{C}\right)$ & 7.916 & 0.65 & & \\
\hline Kinematic viscosity $\left(\mathrm{mm}^{2} / \mathrm{s}\right)\left(40^{\circ} \mathrm{C}\right)$ & 1.056 & 2.1 & & \\
\hline Solubility in water (\%) & Miscible & 100 & & \\
\hline Static dielectric constant $\left(25^{\circ} \mathrm{C}\right)$ & 24.35 & 36.47 & & \\
\hline Octane number & 108.6 & 95.4 & & \\
\hline Cetane number & 5 & $<10$ & 55 & $47-51$ \\
\hline Energy density (MJ/L) & $23.4-26.8$ & 35 & & \\
\hline$\Delta \mathrm{H}_{\mathrm{vap}}(\mathrm{KJ} / \mathrm{mol})$ & 42.590 & 54.8 & & \\
\hline$\Delta \mathrm{Hc}^{\circ}{ }_{\text {liq }}(\mathrm{KJ} / \mathrm{mol})$ & -1367.6 & -2649.6 & & \\
\hline $\mathrm{LD}_{50}$ oral for rat $(\mathrm{mg} / \mathrm{Kg})$ & 7060 & 8800 & & \\
\hline
\end{tabular}

In some research works, GVL has been postulated as a versatile platform molecule, useful as a renewable carbon source for the production of liquid fuels such as gasoline range biofuels $[67,70]$ (Figure 6). For example, methyl tetrahydrofuran (MTHF) formed by GVL hydrogenolysis is a promising fuel since it can be mixed up to $70 \%$ in gasoline and has a high octane number of 87 [71]. Biomass-derived MTHF and n-butyl ether can be blended to achieve the desired fuel properties [72].

At present, most of the studies about LCB as a precursor study the obtaining of levulinic acid since it was proposed as a platform molecule before GVL. However, few studies use biomass as a precursor in one-pot reactions for the production of GVL. To analyze the behavior of the reaction without impurities, some research groups use a mixture of commercial precursors, preventing obstacles caused by interferences like lignin. However, unwanted products called humins are generated during the conversion of polysaccharides and carbohydrates and sugars dehydration and hydration of 5-hydroxymethylfurfural 
(5-HMF) and furfural. Humins are a big problem in the one-pot production of bioproducts on sugar platforms as they decrease reaction yields and deactivate catalysts by poisoning [74-76]. Relevant studies in the literature are shown in Table 3. All these studies are still in the laboratory development stage.

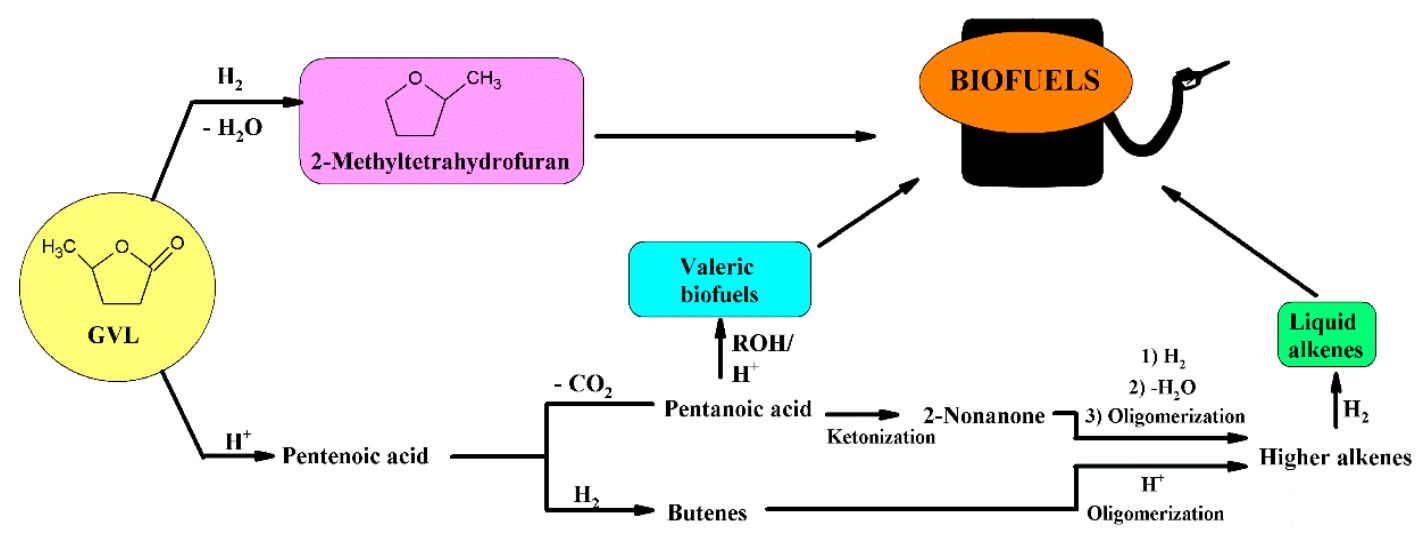

Figure 6. Possible pathways to obtain biofuels from GVL [59,73].

Table 3. GVL production from cellulose, xylose, and platform molecules.

\begin{tabular}{|c|c|c|c|c|}
\hline Precursor & Catalyst & Reaction Conditions & Results & Reference \\
\hline \multirow{2}{*}{$\begin{array}{l}\text { Sugarcane bagasse } \\
\text { (two-stage process) }\end{array}$} & $\begin{array}{l}2 \% \text { acid-activated } \\
\text { bentonite }\end{array}$ & $60 \mathrm{~min}, 200^{\circ} \mathrm{C}$ & $\begin{array}{c}159.17 \text { mg LA/g dry } \\
\text { biomass }\end{array}$ & \multirow[b]{2}{*}{ [77] } \\
\hline & $\begin{array}{l}1 \% \mathrm{Pt} / \mathrm{TiO}_{2}+ \\
\text { acid-activated } \\
\text { bentonite }\end{array}$ & $120-360 \mathrm{~min}, 120-200{ }^{\circ} \mathrm{C}$ & $\begin{array}{c}\approx 100 \% \text { LA conversion, } \\
\text { 95\% GVL selectivity }\end{array}$ & \\
\hline $\begin{array}{l}\text { Sugarcane bagasse } \\
\text { hydrolysis liquor } \\
(20 \% \mathrm{LA})\end{array}$ & $\mathrm{Fe}_{3}(\mathrm{CO})_{12}$ & $15 \mathrm{~h}, 80^{\circ} \mathrm{C}$, imidazole as a base & $50 \%$ GVL mol yield & [78] \\
\hline D-fructose & \multirow{2}{*}{$\mathrm{Ru} / \mathrm{C}+\underset{\text { Trifluoroacetic }}{\text { acid }}$} & $\begin{array}{l}16 \mathrm{~h}, 180^{\circ} \mathrm{C} \text {, formic acid as } \\
\text { hydrogen donor }\end{array}$ & $\begin{array}{l}\text { 100\% conversion, } 52 \% \\
\text { GVL mol yield }\end{array}$ & \multirow{2}{*}{ [79] } \\
\hline D-fructose & & $\begin{array}{l}8 \mathrm{~h}, 94 \text { bar, } 180^{\circ} \mathrm{C} \text {, molecular } \\
\text { hydrogen as hydrogen donor }\end{array}$ & $\begin{array}{l}\text { 100\% conversion, } 62 \% \\
\text { GVL mol yield }\end{array}$ & \\
\hline Furfuryl alcohol & \multirow{3}{*}{$\begin{array}{l}\text { Divinylbenzene with } \\
\text { acid ionic liquid } \\
(\mathrm{PDVB}-\mathrm{IL})+\mathrm{Co} / \mathrm{TiO}_{2}\end{array}$} & \multirow{3}{*}{$\begin{array}{c}12 \mathrm{~h}, 1 \mathrm{~atm}, 150^{\circ} \mathrm{C}, \\
\text { dimethylsulfoxide (DMSO) + } \\
\text { ethanol as a solvent }\end{array}$} & $69 \%$ GVL yield & \multirow{3}{*}{ [80] } \\
\hline $\begin{array}{l}\text { 5-Hydroxymethyl } \\
\text { furfural }\end{array}$ & & & $62 \%$ GVL yield & \\
\hline Fructose & & & $55 \%$ GVL yield & \\
\hline Furfural & \multirow{2}{*}{$\begin{array}{c}\text { Chitosan-Ru/PPh3 + } \\
\text { ZSM-5 }\end{array}$} & \multirow{2}{*}{$30 \mathrm{~h}, 160^{\circ} \mathrm{C}$} & 79\% GVL yield & \multirow{2}{*}{ [81] } \\
\hline Xylose & & & 30-37\% GVL yield & \\
\hline Fructose & \multirow{2}{*}{ Amberlyst-15 } & \multirow{3}{*}{$\begin{array}{c}\text { Methanol/water as a solvent. } \\
\text { Two steps: } \\
5 \mathrm{~h}, 160^{\circ} \mathrm{C} \\
8 \mathrm{~h} \text {, room temperature }+ \\
\text { water/ammonia borane }\end{array}$} & $60 \%$ GVL yield & \multirow{3}{*}{ [82] } \\
\hline Glucose & & & $51 \%$ GVL yield & \\
\hline Cellobiose & Amberlyst-15 + Sn-Beta & & $40 \%$ GVL yield & \\
\hline Furfural & $\begin{array}{l}\mathrm{ZrO}_{2}-[\mathrm{Al}] \mathrm{MFI} \text { zeolite } \\
\text { nanosponge }\end{array}$ & $\begin{array}{c}36 \mathrm{~h}, 170{ }^{\circ} \mathrm{C}, 2 \text {-propanol as a } \\
\text { hydrogen source }\end{array}$ & $\begin{array}{l}100 \% \text { conversion, } 82.8 \% \\
\text { GVL yield }\end{array}$ & [83] \\
\hline Furfural & \multirow{2}{*}{$\begin{array}{c}\text { MWW-type } \\
\text { Zr-Al-SCM-1 zeolites }\end{array}$} & $28 \mathrm{~h}, 170^{\circ} \mathrm{C}$ & $47.3 \%$ GVL yield & \multirow{2}{*}[84]{} \\
\hline Xylose & & $48 \mathrm{~h}, 170^{\circ} \mathrm{C}$ & $36.4 \%$ GVL yield & \\
\hline
\end{tabular}

More accessible, simple, and economical options for producing the multifunctional GVL from carbohydrates need to be further investigated. There are expectations that this 
is possible. There are bottom-up studies based on the optimization of the LA $\rightarrow$ GVL pathway by changing factors such as temperature, type of catalyst, time, and pressure, among others. Knowing the optimal conditions of each of the stages of the cascade reaction system involved in obtaining biofuels from biomass is of great importance. A challenge in this respect is to find a multifunctional catalyst that can perform all these steps without the need for separation or purification of streams [59]. Overcoming each of these challenges represents a step to achieving a large-scale production scheme that takes advantage of each stream from the fractionation of LCB as a precursor of a high-value compound instead of as a source of energy in boilers. In turn, reaching larger scales may represent an improvement in the marketability of biofuels, bioproducts, and biochemicals.

\section{Alternatives for Energy Production from Biomass}

Global forecasts have indicated that, by 2050, the world population will require $70 \%$ more food, $50 \%$ more fuel, $50 \%$ more water, and a $50-80 \%$ reduction in carbon dioxide $\left(\mathrm{CO}_{2}\right)$ emissions to maintain social, political, and climate security [85], and currently, according to estimations, fossil fuels satisfy about $80 \%$ of the world's energy requirement and are responsible for a high share of GHGs emissions [86]. Several raw materials (starch and sugar crops, oilseeds, perennial crops, including wood and grasses) have been proposed or tested for commercial energy. The ideal characteristics of energy sources are high yield (maximum production of dry matter per hectare), low contaminant components, low energy input in production, low cost, and low nutrient requirements [87].

Bioenergy is renewable energy derived from biomass. Besides power and heat, forms of bioenergy include solid, liquid, and gas fuels. These various forms of bioenergy are used in industrial, residential, and commercial applications [88].

\subsection{Solid Biofuels}

The treatment, transportation, storage, and use of biomass in its original form is difficult due to its high moisture content, unspecified form and size, and low specific weight. A solution to these problems is the densification of biomass in pellets and briquettes. Pelleting, briquetting, and torrefaction are significant pretreatment methods and pathways that have emerged to upgrade solid biofuels in the past years [89]. When biomass is concentrated, its specific weight increases from $40-200 \mathrm{~kg} \mathrm{~m}^{-3}$ to $600-800 \mathrm{~kg} \mathrm{~m}^{-3}$ or higher $\left(>1000 \mathrm{~kg} \mathrm{~m}^{-3}\right)$. Consequently, the densification of biomass could reduce the costs of transportation, handling, and storage. Due to their uniform shape and size, densified products (pellets or briquettes) can be easily used, stored, and even further treated [90,91]. Pellets are an excellent and inexpensive solution to replacing oil; they are renewable and inexhaustible and do not pollute the environment. Pellets can be produced from one type or mixed biomass [90]. Although energy generation from biomass is a promising form of energy, it is possible to further enhance biomass before energy generation (with higher heating values and higher density).

Another pretreatment is torrefaction, which is a pyrolysis process where the biomass is subjected to temperatures of about $220-300{ }^{\circ} \mathrm{C}$ for $10 \mathrm{~min}$ to $2 \mathrm{~h}$, in the absence of oxygen and under atmospheric pressure using low heating rates [89]. Besides, a strategy of torrefaction followed by pelletization is an interesting option and offers a solution to the durability and biological degradation of the produced pellets [89].

\subsection{Liquid Biofuels}

Besides the mechanical processing of biomass to obtain bioenergy, several biofuels can be produced from biomass, helping to alleviate demand for petroleum products and improve the greenhouse gas emissions profile of the transportation sector. The production of biofuels and energy from LCB is based on two main routes. Biochemical processes are typically carried out with LCB having a $\mathrm{C} / \mathrm{N}$ ratio lower than 30 and humidity at collection higher than $30 \%$. These processes are based on chemical reactions and use enzymes, mushrooms, and microorganisms. An alternative is thermochemical processes. 
In the last few years, novel biofuels have been produced from LCB, such as bio- $\mathrm{H}_{2}$, butanol, dimethylfuran, and $\gamma$-valerolactone [91].

One of the most important biofuels is ethanol. Ethanol is a well-known biofuel, and it is produced commercially through the fermentation of sugars available in biomass. Ethanol could have several applications (pharmaceutical, cosmetic, solvent, and chemical industries), as energy applications, is commonly used as oxygenating in gasoline is produced from grains, sugar juice, or other renewable agricultural and forestry feedstocks [92]. On the other side, GVL is a novel biofuel that can be produced from cellulose via levulinic acid. GVL can be used as a feedstock to produce liquid fuels and serve as a renewable organic solvent for biomass fractionation and fermentable sugars production [93]. GVL is considered a better alternative to ethanol as a fuel additive because GVL has significantly lower vapor pressure and higher energy density compared to ethanol [63]. Other than ethanol, no azeotrope forms between GVL and water, which probably results in an energy-efficient separation of GVL from an aqueous solution.

A process developed by GlucanBio for fermentable sugar production from biomass using GVL is a promising technology. This process applies to both herbaceous and woody biomass, and GVL can be recovered and recycled after completion of the fractionation process. Preliminary economic analysis shows that ethanol can be produced competitively from the fermentable sugars obtained in this process when $\mathrm{CO}_{2}$ is used for phase separation [93]. Besides, GVL could be a precursor of novel products like MTHF, a promising fuel additive formed through the catalytic hydrogenation of GVL [94], which has an octane number higher than GVL and can blend with gasoline with a ratio up to 70\% [71]. Other options are valeric biofuels that could be prepared by the ring-opening, hydrogenation, and esterification of GVL [95]. Compared with ethanol, 1-butanol, and MTHF, valerate esters possess higher energy densities and suitable polarities comparable to commercial fuels [96].

\section{Technical (Integration Opportunities), Economic, and Environmental Perspectives \\ 4.1. Technical and Environmental Considerations}

Densification strategies are currently being developed on a commercial scale. The conventional processes for the production of pellets and briquettes start with biomass drying. Then, depending on the size of the initial biomass particles, grinding, and finally, pelletizing or briquetting followed by final conditioning are carried out $[90,91,97]$.

Commercial torrefaction development is in its early stage. The increasing demand for torrefied biomass forces the developers to accelerate the scaling up of their technologies and move towards their market introduction. Reactor technologies originally designed for other applications were modified for their application in torrefaction. The particle size and characteristics of the processed feedstock generally play a significant role in the selection of the torrefaction reactor [89].

Compared to the raw biomass, solid biofuel (i.e., biochar) has better grindability and hydrophobicity, improved homogenization, and lower moisture content $[97,98]$. The solid biofuel, when densified, has superior characteristics, similar to coal in terms of handling, milling, and transport. Depending on the species, torrefaction temperature, and residence time, its net calorific value (LHV) may vary in the range of $18-22 \mathrm{MJ} / \mathrm{kg}$ for herbaceous biomass feedstock and 20-24 MJ $/ \mathrm{kg}$ for woody biomass [89,98]. According to the process conditions, the final product contains $50-70 \%$ of the initial mass and $75-90 \%$ of the initial energy [89].

Bioethanol production has passed through several technological advancements, which have increased its global production capacity $[99,100]$. Most of the commercial bioethanol production plants depend on sugar and starch-based feedstocks, such as corn in the USA [101]; sugarcane in Brazil [102]; and wheat, sugar beet, and barley in Europe [103]. First-generation bioethanol is generally produced using starch or sugar-based crops such as barley, sugarcane, corn, wheat, and sweet sorghum through a simple fermentation of sugar extracted. Despite the successes recorded globally in commercializing $1 \mathrm{G}$ bioethanol, 
it is still facing some constraints such as food versus fuel debate (use of land suitable for food production for bioenergy crop production; sugar is also considered as human food), high cost of feedstock, high impact on the environment except for sugarcane bioethanol, negative impact on biodiversity and competition with scarce water resources in some regions. These constraints have stimulated intensive research in the bioethanol production from alternative feedstocks such as lignocellulosic biomass, also known as $2 \mathrm{G}$ bioethanol production [103].

The integration of $1 \mathrm{G}$ and 2G-SHF bioethanol production from a techno-economic perspective has been widely investigated. Several alternatives such as (i) stand-alone $1 \mathrm{G}$ and $2 \mathrm{G}$ processes; (ii) $1 \mathrm{G}$ with combined heat and power; (iii) stand-alone $2 \mathrm{G}$ ethanol production from co-fermentation of xylose and glucose sugars derived from hydrolysis of pretreated biomass; (iv) stand-alone $2 \mathrm{G}$ ethanol production from fermentation of only glucose sugars with the option of biogas production from the xylose sugars, integrated $1 \mathrm{G}-2 \mathrm{G}$ process using all the bagasse for ethanol production; (v) integrated 1G-2G process using part of the bagasse as fuel in the boiler for electricity generation; and (vi) flexible $1 \mathrm{G}-2 \mathrm{G}$ process producing both bioethanol and electricity were investigated. Amongst the different scenarios considered, integrated $1 \mathrm{G}-2 \mathrm{G}$ processes using all the sugars for ethanol production has the best economic performance [103].

Stand-alone $2 \mathrm{G}$ plants for ethanol production have high technological risks, large economic investments, and relatively low economic returns. Integration of $1 \mathrm{G}$ and $2 \mathrm{G}$ ethanol is reported as an opportunity to lower the investment risk and costs since a significant part of the necessary downstream infrastructure is already available, enabling the introduction of $2 \mathrm{G}$ ethanol production [104]. On the other hand, comparing integrated and stand-alone first generation plants, the first ones have higher investment risks but also have relatively higher revenues [104]. The main factors influencing the cost of $2 \mathrm{G}$ ethanol are the feedstock type and cost, conversion yield, energy use, and the valorization of the coproducts $[104,105]$. The additional revenue from coproducts significantly influences the economic feasibility of the biofuels industry. Ethanol yield and energy demand are critical factors in ethanol production costs from lignocellulosic materials [105].

For GVL production processes, few studies have been performed to evaluate technical factors of GVL production, mainly from ethyl levulinate (EL) and corn stover. Processing $133,000 \mathrm{t} / \mathrm{y}$ of EL and $1860 \mathrm{t} / \mathrm{y}$ of $\mathrm{H}_{2}$ required $249 \mathrm{MW}$ of heating, $254 \mathrm{MW}$ of cooling, and 2.8 MW of electricity. Most heating energy (65\%) was used to adjust operating conditions in the GVL production subsystem. The GVL recovery subsystem is the second-largest heating energy consumption (35\%). In this process, about 92,000 t/y of GVL and 42,000 t/y of ethanol are produced [106]. The energy analysis of the integrated processing of 700,000 $\mathrm{t} / \mathrm{y}$ of corn stover was performed based on process simulation results. The integrated process could produce $34,300 \mathrm{t} / \mathrm{y}$ of GVL and 17,000 t/y of PG (propyl guaiacol). The energy requirements were estimated to be $162.5 \mathrm{MW}$ for heating, 102.0 MW for cooling, and 5.6 MW for electricity. The energy content in humins and unconverted lignin could be used to generate heat and electricity (satisfying a portion of the heating energy requirements of the process) [107].

Another study analyzes two types of processes, namely the single processing of cellulose by using lignin-derived propyl guaiacol solvent (Process A); and the simultaneous processing of cellulose and hemicelluloses by using gamma-valerolactone solvent derived from cellulose and hemicelluloses (Process B). Assuming a $2000 \mathrm{t} / \mathrm{d}$ of corn stover capacity, heating, cooling, and electricity is required. Heating requirements to recover GVL with high purity were $137 \mathrm{MW}$ (Process A) and $186 \mathrm{MW}$ (Process B), but process B (375 t/d) produced more GVL than Process A (98 t/d) [108].

The efficiency, flexibility, profitability, and sustainability of the bioethanol and GVL production from sugar-based feedstock can be enhanced using process integration strategies. Several production strategies were developed to obtain a cost-effective process production $[103,105]$, and one of the most important is process integration (heat/energy 
and mMass integration) [109]. Table 4 shows some improvements obtained through process integration.

Table 4. Integration strategies for GVL and ethanol are shown.

\begin{tabular}{|c|c|c|c|c|}
\hline Feedstock & Main Product & Integration Strategy & Improvement & Ref \\
\hline Sugarcane & Bio-ethanol & EI & $\begin{array}{l}\text { Energy reduction of more than } 50 \% \text { compared } \\
\text { without any energy integration. }\end{array}$ & [110] \\
\hline Sugarcane & Bio-ethanol & EI & $\begin{array}{c}\text { Up to } 71 \% \text { of steam to process without } \\
\text { energy integration. }\end{array}$ & [111] \\
\hline Sugarcane bagasse & Bio-ethanol & EI and MI & $\begin{array}{l}\text { A reduction in steam consumption } \\
\text { could reach } 34 \% \text {. }\end{array}$ & [112] \\
\hline $\begin{array}{c}\text { Corn and } \\
\text { switchgrass }\end{array}$ & Bio-ethanol & EI and MI & $\begin{array}{c}\text { Water and energy consumption could be reduced } \\
\text { by } 50 \% \text { compared to the values reported } \\
\text { in the literature. }\end{array}$ & [113] \\
\hline Ethyl levulinate & GVL & EI & $\begin{array}{l}\text { Heating and cooling requirements could be } \\
\text { reduced by almost } 1 \% \text { because most of the } \\
\text { temperature of hot streams was higher than } \\
\text { cold streams. }\end{array}$ & [106] \\
\hline Corn stover & GVL & EI & $\begin{array}{l}\text { The heating requirements of the process could } \\
\text { decrease by }>47 \% \text {. }\end{array}$ & [107] \\
\hline Corn stover & GVL & EI & $\begin{array}{l}\text { The heating requirements could be reduced up to } \\
52 \% \text { and cooling requirements could be reduced up } \\
\text { to } 49 \% \text { of their initial values. }\end{array}$ & [108] \\
\hline
\end{tabular}

EI: energy integration; MI: mass integration.

For the production of sustainable biofuels, some concerns must be considered such as (i) to be carbon neutral; (ii) not to affect the quality, quantity, and rational use of available natural resources; (iii) not to have undesirable social consequences; (iv) to contribute to the social-economic development and equity; and (v) not to affect the biodiversity [114].

For solids biofuels, it was highlighted a lack of LCA studies in the literature [115]. The needed energy for the pelletization of biomass feedstock could reach high values. The drying stage is the main contributor to the environmental impacts of the pelleting system. Comparing the environmental impact of conventional and torrefied wood pellets using an LCA study, when torrefied pellets were applied instead of conventional ones, a reduction of fossil fuel consumption and GHG emissions were estimated [89].

Regarding environmental aspects, $1 \mathrm{G}$ bioethanol contributes to greenhouse gas emissions, being the most critical reported environmental impact emanating from land-use change and water utilization during crop cultivation [116]. 1G bioethanol production has a higher environmental impact than that of $2 \mathrm{G}$ [103]. Based on the life cycle assessment, the flexible integrated $1 \mathrm{G}-2 \mathrm{G}$ process for producing both ethanol and electricity has the highest avoidable carbon dioxide emissions compared to other scenarios, e.g., using all the sugars for ethanol production [103].

\subsection{Economic Considerations}

The prices of lignocellulosic wastes could be a critical factor to define the production process and final product to be obtained in a biorefinery platform. Values of agro-industrial wastes could be higher than USD 110/t and those of forest wastes could be higher than USD 123/t [117]. In the case of solids biofuels, the market prices depend on each region. The pellets market price could vary between USD 125/t up to USD 170/t [118-120], and the minimum selling price (MSP) of wood chips briquettes, torrefied-wood chips briquettes, and biochar was USD 162, USD 274, and USD 1044, respectively [121].

The world production of ethanol fuel rose by 13\% from 2015 to 2019, increasing from 97 to 110 billion liters (Table 5). Among the three main producers (the USA, Brazil, and the 
European Union) the USA, and Brazil were the countries with the biggest fuel production ( $85 \%)$. In 2019, the global ethanol market size was valued at 89.1 billion USD, and the forecast 2020-2027 indicates a compound annual growth rate (CAGR) of 4.8\% [122]. Also, for the period 2020-2027, 2G ethanol demand is expected to register a CAGR of about $6 \%$, mainly for the alcoholic beverages and disinfectant industries [123]. Currently, the prices of ethanol and crude oil are highly correlated, which means that the profitability of producing ethanol is closely linked to the ups and downs of global crude oil prices [124].

Table 5. World ethanol fuel production per year, in billion liters.

\begin{tabular}{cccccc}
\hline & $\mathbf{2 0 1 5}$ & $\mathbf{2 0 1 6}$ & $\mathbf{2 0 1 7}$ & $\mathbf{2 0 1 8}$ & $\mathbf{2 0 1 9}$ \\
\hline United States & 56.0 & 58.3 & 60.2 & 60.8 & 59.6 \\
Brazil & 27.2 & 25.5 & 25.1 & 30.2 & 32.5 \\
European Union & 5.1 & 5.1 & 5.4 & 5.5 & 5.2 \\
China & 2.9 & 2.5 & 3.0 & 2.9 & 3.8 \\
Canada & 1.7 & 1.7 & 1.7 & 1.7 & 2.0 \\
India & 0.7 & 1.1 & 0.8 & 1.6 & 1.9 \\
Thailand & 1.2 & 1.3 & 1.5 & 1.5 & 1.6 \\
Argentina & 0.8 & 0.9 & 1.1 & 1.1 & 1.1 \\
Rest of the World & 1.5 & 1.8 & 1.7 & 2.0 & 2.0 \\
Total & 97 & 98 & 101 & 107 & 110 \\
\hline
\end{tabular}

Prepared with data from the Renewable Fuels Association (RFA), 2020. http://ethanolrfa.org/.

In the case of GVL, there is little information available about its global market and future trends. Studies have recently been carried out on production costs on production processes. For example, from EL, the minimum selling price (MSP) of GVL was USD $1.69 / \mathrm{kg}$, which was in the range of the current GVL market price (USD 1.25-3.88/kg). The largest MSP components of GVL were EL price, steam price, and catalyst price [106]. From corn stover, the selling price of GVL was determined as USD 3081/t, which was calculated by the difference between the incomes obtained by selling byproducts. The determined MSP was USD $3081 / t$, which is $20.6 \%$ lower than the conventional GVL market price (>USD 3880/t) [107]. Another study reported that the MSP of GVL was $2.36 \mathrm{USD} / \mathrm{kg}$ and could decrease by USD $0.88 / \mathrm{kg}$ [108].

\section{Environmental Concerns about Lignocellulosic Wastes and Sustainable Biomass Valorization}

Lignocellulosic residues generate pollution, high land occupation, can cause fires, and harm human health. The sustainable biomass valorization consists of the integral use of biomass, reduction of generated waste, reuse of reagents (catalysts, solvents, etc.), and low energy consumption, among others. Biorefinery starts with the biomass fractionation into dissolved lignin, hemicelluloses, and solid substrate. Biomass fractionation, known as pretreatment, is carried out to enhance the reactivity and accessibility of carbohydrates with slight modifications in the structure to increase the sugar yields [125].

Biomass undergoes different chemical changes during the conversion process depending on the reagents and conditions used in the process. Hydrolysis, hydrogenolysis, hydration, dehydration, fermentation, etc., are the primary chemical reactions in biorefinery [126]. Hydrolysis is the first and foremost step in the biochemical conversion of biomass and is carried out by different chemicals and hydrothermal processes [127]. The use of chemicals provides a strong effect to fractionate the biomass structure into different fractions and their corresponding monomers favoring later conversions.

The conversion of biomass into chemicals and materials involves separation, extraction, and chemical conversion [128]. Besides, several reagents (solvents, catalysts, others) used in the processes require their previous analysis and evaluation. The current process economy must be improved, for example, pre-treatment steps, which are energy-intensive and generate significant quantities of waste during acid or base neutralization and enzyme separation. Furthermore, fractionation using mineral acids (like sulfuric acid) often 
degrades all lignocellulosic components resulting in a solid material difficult to treat or liquors rich in furfural and $\mathrm{C} 1-\mathrm{C} 2$ acids, problematic for subsequent fermentation because of yeast growth inhibition [129]. In this sense, there is a growing interest in aqueous-phase processing of cellulosic-derived sugars using heterogeneous catalysis as a complementary processing method to enzymatic routes. Catalyst development should thus focus on the use of tailored porous solids as high area supports to enhance reactant accessibility to active acid/base groups. Catalysts should have tunable hydrophobicity, hydrothermal stability over a wide $\mathrm{pH}$ range, effective functionalization, and resistance to in-situ leaching during the reaction [129]. Cellulose hydrolysis is experiencing a new research and development cycle, in which this reaction is carried out over solid catalysts and coupled to other reactions for its better utilization [130].

For solvents selection, it is necessary to take into account considerations concerning (i) solubility or functionality (for determining the functionality of a solvent for a particular solute), (ii) environmental and health safety (EHS) (solvent must be balanced with the cost, toxicity, environmental, and health safety), (iii) recyclability (reuse of solvents is one of the crucial green criteria of biorefinery), and (iv) vapor pressure (vital parameter for determining the safety of the biorefinery operation) [131]. Additionally, gas, liquid, and solid effluents are generated after the different biorefining process steps. These effluents could be treated separately using different methods to ensure their discharge under environmental regulation standards. Wastewater treatment (WWT) methods involve chemical, physical, and biological treatments. Biological treatment allows the recovery of organic matter and nutrients, but it demands higher energy consumption than physical treatments. Physical treatments need lower energy but are less effective, and chemical treatment is an intermediate choice [132]. The catalyst in liquid streams could be regenerated depending on its concentration, which relies mainly on the catalyst type, its formulation, and the operational conditions that it was exposed to [132-134]. Water reuse strategies and technologies are restricted by the suspended solid content. The after-treatment solid waste could be used as fuel [132].

For the global evaluation, and besides the production factors, environmental aspects must be taken into account in the stages before and after the biomass conversion process. Related to the land used to produce lignocellulosic biomass for production, distribution, and final use of the biofuels, some factors could be critical in the global process of biofuels production, which makes it necessary to evaluate the global impact of the processes through life cycle assessment, environmental impact assessment, and modeling, among others [135]. The evaluation of the life cycle of chemicals, products, and materials of fossil and renewable sources is also significant to assess the environmental impact [45].

\section{Conclusions}

The state of the art of biofuels and energy production from lignocellulosic biomass shows that the implementation of biorefineries platforms is a sustainable production strategy. Biorefineries have a promising future. Nevertheless, to optimally exploit their full potential sustainably, technological innovations, and public policies from governments and international organizations must be directed to the production of fuels and high-value products from lignocellulosic biomass. The biorefinery development requires government policies accompanied with subsidies, qualified labor, visibility of advantages, biofuel mix, and the cooperation between various sectors (researchers, government, universities, investors, and society).

For solid biofuels, pretreatment methods and pathways like pelleting, briquetting, and torrefaction have emerged. Besides the mechanical processing of biomass to obtain bioenergy, several alternatives to produce conventional and novel biofuels have been developed from LCB, such as bioethanol and $\gamma$-valerolactone.

The processes for solid biofuels production are consolidated at a commercial scale, and it is possible to obtain products with better energy, environmental, and economic 
properties than the initial biomass. However, more development of environmental concerns is necessary.

Considering energy, economic, and environmental factors, current production processes for $2 \mathrm{G}$ bioethanol and GLV are promising. However, there is a low investment in research on the production of biocompounds from lignocellulosic residues. For large-scale 2G bioethanol or GVL production to be profitable, studies must cover several lines, including the best combination of pretreatments and subsequent treatments, current recovery, product, and by-product obtaining; energy consumption; and the use of water, reagents, enzymes, and yeasts, among others.

Author Contributions: Conceptualization, M.C.A. and M.E.V.; Methodology, M.C.A. and M.E.V.; validation M.C.A. and M.E.V.; Investigation, N.M.C., G.G., C.M.M., and J.K.; Data curation, M.E.V.; Writing—original draft preparation, M.C.A., M.E.V., N.M.C., G.G., C.M.M., and J.K.; Writing一review and editing, M.C.A. and M.E.V.; Supervision, M.C.A. and M.E.V.; Project administration, M.C.A.; Funding acquisition, M.C.A. All authors have read and agreed to the published version of the manuscript.

Funding: This research received no external funding.

Informed Consent Statement: Not applicable.

Data Availability Statement: Data sharing not applicable.

Acknowledgments: To the National Scientific and Technical Research Council (CONICET) and the National University of Misiones (UNaM).

Conflicts of Interest: The authors declare no conflict of interest.

\section{References}

1. Bhatt, S.M.; Bal, J.S. Bioprocessing Perspective in Biorefineries. In Sustainable Approaches for Biofuels Production Technologies; Srivastava, N., Srivastava, M., Mishra, P.K., Upadhyay, S.N., Ramteke, P.W., Gupta, V.K., Eds.; Springer: Cham, Switzerland, 2019; pp. 1-23. [CrossRef]

2. Agbor, V.B.; Cicek, N.; Sparling, R.; Berlin, A.; Levin, D.B. Biomass pretreatment: Fundamentals toward application. Biotechnol. Adv. 2011, 29, 675-685. [CrossRef]

3. Pishvaee, M.S.; Mohseni, S.; Bairamzadeh, S. An overview of biomass feedstocks for biofuel production. In Biomass to Biofuel Supply Chain Design and Planning under Uncertainty; Elsevier: Amsterdam, The Netherlands, 2021; pp. 1-20. [CrossRef]

4. International Energy Agency (IEA). Technology Roadmap Biofuels for Transport; International Energy Agency (IEA): Paris, France, 2011.

5. Sharma, D.; Saini, A. Introduction to Lignocellulosic Ethanol. In Lignocellulosic Ethanol Production from A Biorefinery Perspective; Springer: Singapore, 2020; pp. 1-21. [CrossRef]

6. Yan, K.; Yang, Y.; Chai, J.; Lu, Y. Catalytic reactions of gamma-valerolactone: A platform to fuels and value-added chemicals. Appl. Catal. B Environ. 2015, 179, 292-304. [CrossRef]

7. Saini, J.K.; Gupta, R.; Hemansi; Verma, A.; Gaur, P.; Saini, R.; Shukla, R.; Kuhad, R.C. Integrated Lignocellulosic Biorefinery for Sustainable Bio-Based Economy. In Sustainable Approaches for Biofuels Production Technologies; Srivastava, N., Srivastava, M., Mishra, P.K., Upadhyay, S.N., Ramteke, P.W., Gupta, V.K., Eds.; Springer: Cham, Switzerland, 2019; pp. 25-46. [CrossRef]

8. Kamm, B.; Gruber, P.R.; Kamm, M. Biorefineries-Industrial Processes and Products. In Ullmann's Encyclopedia of Industrial Chemistry; Wiley-VCH Verlag GmbH \& Co. KGaA: Weinheim, Germany, 2007; pp. 660-687. [CrossRef]

9. Tanneru, S.K.; Steele, P.H. Direct hydrocracking of oxidized bio-oil to hydrocarbons. Fuel 2015, 154, 268-274. [CrossRef]

10. Furimsky, E. Catalytic hydrodeoxygenation. Appl. Catal. A Gen. 2000, 199, 147-190. [CrossRef]

11. Stefanidis, S.D.; Kalogiannis, K.G.; Lappas, A.A. Co-processing bio-oil in the refinery for drop-in biofuels via fluid catalytic cracking. WIREs Energy Environ. 2018, 7, e281. [CrossRef]

12. Shell Energy Transition Report. Available online: https://www.shell.com/energy-and-innovation/the-energy-future/shell-ener gy-transition-report.html (accessed on 1 October 2020).

13. Graham, K. Major Oil Companies Quietly Investing in Clean Energy Startups. Available online: http:/ / www.digitaljournal.com /business / major-oil-companies-quietly-investing-in-clean-energy-start-ups/article/500095 (accessed on 15 September 2020).

14. Burgermeister, J. Germany's Chemical Industry Looks at Switching to Biomass. Available online: https://www.renewableenerg yworld.com/2009/06/15/germanys-chemical-industry-looks-at-switching-to-biomass/\#gref (accessed on 10 September 2020).

15. Pérez, V.; Pascual, A.; Rodrigo, A.; García Torreiro, M.; Latorre-Sánchez, M.; Coll Lozano, C.; David-Moreno, A.; Oliva-Dominguez, J.M.; Serna-Maza, A.; Herrero García, N.; et al. Integrated innovative biorefinery for the transformation of municipal solid waste into biobased products. In Waste Biorefinery; Bhaskar, T., Pandey, A., Rene, E.R., Tsang, D.C.W., Eds.; Elsevier: Amsterdam, The Netherlands, 2020; pp. 41-80. ISBN 978-0-12-818228-4. [CrossRef] 
16. Luo, L.; van der Voet, E.; Huppes, G. Biorefining of lignocellulosic feedstock-Technical, economic and environmental considerations. Bioresour. Technol. 2010, 101, 5023-5032. [CrossRef] [PubMed]

17. Vallejos, M.E.; Kruyeniski, J.; Area, M.C. Second-generation bioethanol from industrial wood waste of South American species. Biofuel Res. J. 2017, 15, 654-667. [CrossRef]

18. Mendieta, C.M.; Vallejos, M.E.; Felissia, F.E.; Chinga-Carrasco, G.; Area, M.C. Review: Bio-polyethylene from Wood Wastes. J. Polym. Environ. 2019, 28, 1-16. [CrossRef]

19. Mendieta, C.M.; Felissia, F.E.; Arismendy, A.M.; Kruyeniski, J.; Area, M.C. 2G Bioethanol Production from Pine by SHF and SSF Strategies. Rev. Int. Fabr. Pasta Pap. 2020, 2-3, 42-43. Available online: https://dialnet.unirioja.es/servlet/articulo?codigo=7613 629 (accessed on 8 January 2021).

20. Mendes, C.V.T.; Vergara, P.; Carbajo, J.M.; Villar, J.C.; dos Santos Rocha, J.M.; de Sousa, M.D.G.V. Bioconversion of pine stumps to ethanol: Pretreatment and simultaneous saccharification and fermentation. Holzforschung 2020, 74, 212-216. [CrossRef]

21. Thangavelu, S.K.; Ahmed, A.S.; Ani, F.N. Review on bioethanol as alternative fuel for spark ignition engines. Renew. Sustain. Energy Rev. 2016, 56, 820-835. [CrossRef]

22. Prasad, S.; Singh, A.; Joshi, H.C. Ethanol as an alternative fuel from agricultural, industrial and urban residues. Resour. Conserv. Recycl. 2007, 50, 1-39. [CrossRef]

23. Alonso, D.M.; Bond, J.Q.; Dumesic, J.A. Catalytic conversion of biomass to biofuels. Green Chem. 2010, 12, 1493-1513. [CrossRef]

24. Das, P.; Stoffel, R.B.; Area, M.C.; Ragauskas, A.J. Effects of one-step alkaline and two-step alkaline/dilute acid and alkaline/steam explosion pretreatments on the structure of isolated pine lignin. Biomass Bioenergy 2019, 120, 350-358. [CrossRef]

25. Arismendy, A.M.; Villa Retrepo, A.F.; Alcaraz, W.; Chamorro, E.R.; Area, M.C. Optimization of enzymatic hydrolysis of rice husk. RECyT 2019, 21, 64-70. [CrossRef]

26. Arismendy, A.M.; Felissia, F.; Mendieta, C.; Chamorro, E.; Area, M.C. Improvement of bioethanol production from rice husks. Cellul. Chem. Technol. 2020, 54, 689-698. [CrossRef]

27. Balat, M. Production of bioethanol from lignocellulosic materials via the biochemical pathway: A review. Energy Convers. Manag. 2011, 52, 858-875. [CrossRef]

28. Araque, E.; Parra, C.; Freer, J.; Contreras, D.; Rodríguez, J.; Mendonça, R.; Baeza, J. Evaluation of organosolv pretreatment for the conversion of Pinus radiata D. Don to ethanol. Enzyme Microb. Technol. 2008, 43, 214-219. [CrossRef]

29. Neves, P.V.; Pitarelo, A.P.; Ramos, L.P. Production of cellulosic ethanol from sugarcane bagasse by steam explosion: Effect of extractives content, acid catalysis and different fermentation technologies. Bioresour. Technol. 2016, 208, 184-194. [CrossRef]

30. Area, M.C.; Vallejos, M.E.; Bengoechea, D.I.; Esteban, F.F.; Paola, D.E.; Betiana, S.R. Biorrefinería a Partir de Residuos Lignocelulósicos. Conversión de Residuos a Productos de Alto Valor; Area, M.C., Vallejos, M.E., Eds.; Saarbrücke; Editorial Académica Española: Rīgā, Latvia, 2012. ISBN 978-3-659-05295-8.

31. Arismendy, A.M.; Sequeira, M.J.; Felissia, F.E.; Area, C.M.; Chamorro, E.R. Evaluation of Fermentative Strains in Simultaneous Hydrolysis and Fermentation (SSF) of Rice Husk for Bioethanol Production. Rev. Tecnol. Cienc. 2015, 30, $357-363$.

32. Manfredi, A.P.; Ballesteros, I.; Sáez, F.; Perotti, N.I.; Martínez, M.A.; Negro, M.J. Integral process assessment of sugarcane agricultural crop residues conversion to ethanol. Bioresour. Technol. 2018, 260, 241-247. [CrossRef] [PubMed]

33. McIntosh, S.; Zhang, Z.; Palmer, J.; Wong, H.; Doherty, W.O.S.; Vancov, T. Pilot-scale cellulosic ethanol production using eucalyptus biomass pre-treated by dilute acid and steam explosion. Biofuels Bioprod. Biorefining 2016, 10, 346-358. [CrossRef]

34. Giang, T.; Lunprom, S.; Liao, Q.; Reungsang, A.; Salakkam, A. Enhancing hydrogen production from Chlorella sp. biomass by pre-hydrolysis with Simultaneous Saccharification and Fermentation (PSSF). Energies 2019, 12, 908. [CrossRef]

35. Stoffel, R.B.; Neves, P.V.; Felissia, F.E.; Ramos, L.P.; Gassa, L.M.; Area, M.C. Hemicellulose extraction from slash pine sawdust by steam explosion with sulfuric acid. Biomass Bioenergy 2017, 107, 93-101. [CrossRef]

36. Vedoya, C.I.; Vallejos, M.E.; Area, M.C.; Felissia, F.E.; Raffaeli, N.; da Silva Curvelo, A.A. Hydrothermal treatment and organosolv pulping of softwood assisted by carbon dioxide. Ind. Crops Prod. 2020, 147, 112244. [CrossRef]

37. Imlauer-Vedoya, C.M.; Vergara-Alarcón, P.; Area, M.C.; Revilla, E.; Felissia, F.E.; Villar, J.C. Fractionation of Pinus radiata wood by combination of steam explosion and organosolv delignification. Maderas. Cienc. Tecnol. 2019, 21, 587-598. [CrossRef]

38. Kruyeniski, J.; Ferreira, P.J.T.; Videira Sousa Carvalho, M. da G.; Vallejos, M.E.; Felissia, F.E.; Area, M.C. Physical and chemical characteristics of pretreated slash pine sawdust influence its enzymatic hydrolysis. Ind. Crops Prod. 2019, 130, 528-536. [CrossRef]

39. Mohsenzadeh, A.; Zamani, A.; Taherzadeh, M.J. Bioethylene Production from Ethanol: A Review and Techno-economical Evaluation. ChemBioEng Rev. 2017, 4, 75-91. [CrossRef]

40. Cortés, M.G.; Gallo, L.C.; Carvajal, A.Y.; Suárez, E.G. La integración de procesos en el esquema de una biorrefinería. Afinidad 2014, 568, 274-278.

41. De Assis, C.A.; Gonzalez, R.; Kelley, S.; Jameel, H.; Bilek, T.; Daystar, J.; Handfield, R.; Golden, J.; Prestemon, J.; Singh, D. Risk management consideration in the bioeconomy. Biofuels Bioprod. Biorefining 2017, 11, 549-566. [CrossRef]

42. Brown, T.R. A techno-economic review of thermochemical cellulosic biofuel pathways. Bioresour. Technol. 2015, 178, 166-176. [CrossRef] [PubMed]

43. Kang, Q.; Appels, L.; Tan, T.; Dewil, R. Bioethanol from Lignocellulosic Biomass: Current Findings Determine Research Priorities. Sci. World J. 2014, 2014, 298153. [CrossRef] 
44. Santos Meneses, T.M. Autohidrólisis y Deslignificación Organosolv de Madera de Pinus Radiata Para la Recuperación de Hemicelulosas y Lignina con Aprovechamiento de la Fracción Celulósica por vía Enzimática, Universidad Complutense de Madrid, Facultad de Ciencias Químicas. 2018. Available online: https:/ / eprints.ucm.es/49065 (accessed on 27 December 2020).

45. Nguyen, L.K.; Na, S.; Hsuan, Y.G.; Spatari, S. Uncertainty in the life cycle greenhouse gas emissions and costs of HDPE pipe alternatives. Resour. Conserv. Recycl. 2020, 154, 104602. [CrossRef]

46. Rosales-Calderon, O; Arantes, V. A review on commercial-scale high-value products that can be produced alongside cellulosic ethanol. Biotechnol. Biofuels 2019, 12, 240. [CrossRef]

47. Nizami, A.S.; Rehan, M.; Waqas, M.; Naqvi, M.; Ouda, O.K.; Shahzad, K.; Miandad, R.; Khan, M.Z.; Syamsiro, M.; Ismail, I.M.I.; et al. Waste biorefineries: Enabling circular economies in developing countries. Bioresour. Technol. 2017, 241, 1101-1117. [CrossRef] [PubMed]

48. Kruyeniski, J. Influence of Pretreatment of Forestry-Industrial Waste on Bioethanol Production. Ph.D. Thesis, Universidad Nacional de Misiones, Misiones, Argentina, 2017.

49. Commission, E. Case Studies of Market-Making in the Bioeconomy. Available online: https://ec.europa.eu/research/bioecono my/pdf/13-case-studies-0809102014_en.pdf (accessed on 27 December 2020).

50. Sapp, M. India Approves \$253.9 Million in Gap Funding for 2G Ethanol. Available online: https:/ /www.biofuelsdigest.com/bdi gest/2019/02/28/india-approves-253-9-million-in-gap-funding-for-2g-ethanol/ (accessed on 27 December 2020).

51. FAO. Case Studies on Bioenergy Policy and Law: Options for Sustainability; FAO: Rome, Italy, 2009.

52. Ackom, E.K. Biofuel Sustainability_Case Studies and Practical Lessons for South-South Experience Sharing. Global Network on Energy for Sustainable Development (GNESD). UNEP DTU Partnership. Technical University Denmark (DTU); Global Network on Energy for Sustainable Development: New Delhi, India, 2016.

53. CIFOR. Technologies to Produce Liquid Biofuels for Transportation; CIFOR: Bogor, Indonesia, 2011.

54. IFEU. Biofuels Screening Toolkit_Guidelines for Decision Makers; IFEU: Heidelberg, Germany, 2013.

55. BECOOL. Brazil-EU Cooperation for Development of Advanced Lignocellulosic Biofuels. Available online: https://www.becool project.eu/about (accessed on 27 December 2020).

56. Rackemann, D.W.; Doherty, W.O.S. The conversion of lignocellulosics to levulinic acid. Biofuels Bioprod. Biorefin. 2011, 5, 198-214. [CrossRef]

57. Yu, Z.; Lu, X.; Xiong, J.; Li, X.; Bai, H.; Ji, N. Heterogeneous catalytic hydrogenation of levulinic acid to $\gamma$-Valerolactone with formic acid as internal hydrogen source. ChemSusChem 2020, 13, 2916-2930. [CrossRef] [PubMed]

58. Alonso, D.M.; Wettstein, S.G.; Dumesic, J.A. Bimetallic catalysts for upgrading of biomass to fuels and chemicals. Chem. Soc. Rev. 2012, 41, 8075-8098. [CrossRef] [PubMed]

59. Climent, M.J.; Corma, A.; Iborra, S. Conversion of biomass platform molecules into fuel additives and liquid hydrocarbon fuels. Green Chem. 2014, 16, 516-547. [CrossRef]

60. Singh, R.; Shukla, A.; Tiwari, S.; Srivastava, M. A review on delignification of lignocellulosic biomass for enhancement of ethanol production potential. Renew. Sustain. Energy Rev. 2014, 32, 713-728. [CrossRef]

61. Zhu, S.; Guo, J.; Wang, X.; Wang, J.; Fan, W. Alcoholysis: A promising technology for conversion of lignocellulose and platform chemicals. ChemSusChem 2017, 10, 2547-2559. [CrossRef] [PubMed]

62. Horváth, I.T. Solvents from nature. Green Chem. 2008, 10, 1024-1028. [CrossRef]

63. Horváth, I.T.; Mehdi, H.; Fábos, V.; Boda, L.; Mika, L.T. $\gamma$-Valerolactone-A sustainable liquid for energy and carbon-based chemicals. Green Chem. 2008, 10, 238-242. [CrossRef]

64. Bruno, T.J.; Wolk, A.; Naydich, A. Composition-explicit distillation curves for mixtures of gasoline and diesel fuel with $\gamma$ valerolactone. Energy Fuels 2010, 24, 2758-2767. [CrossRef]

65. Bereczky, Á.; Lukács, K.; Farkas, M.; Dóbé, S. Effect of $\gamma$-Valerolactone blending on engine performance, combustion characteristics and exhaust emissions in a diesel engine. Nat. Resour. 2014, 5, 177-191. [CrossRef]

66. Lê, H.Q.; Zaitseva, A.; Pokki, J.-P.; Ståhl, M.; Alopaeus, V.; Sixta, H. Solubility of organosolv lignin in $\gamma$-Valerolactone/water binary mixtures. ChemSusChem 2016, 9, 2939-2947. [CrossRef]

67. Tang, X.; Zeng, X.; Li, Z.; Hu, L.; Sun, Y.; Liu, S.; Lei, T.; Lin, L. Production of $\gamma$-valerolactone from lignocellulosic biomass for sustainable fuels and chemicals supply. Renew. Sustain. Energy Rev. 2014, 40, 608-620. [CrossRef]

68. Covinich, L.G.; Clauser, N.M.; Felissia, F.E.; Vallejos, M.E.; Area, M.C. The challenge of converting biomass polysaccharides into levulinic acid through heterogeneous catalytic processes. Biofuels Bioprod. Biorefin. 2020, 14, 417-445. [CrossRef]

69. Xin, J.; Yan, D.; Ayodele, O.; Zhang, Z.; Lu, X.; Zhang, S. Conversion of biomass derived valerolactone into high octane number gasoline with an ionic liquid. Green Chem. 2015, 17, 1065-1070. [CrossRef]

70. Wang, H.; Wu, Y.; Jin, T.; Dong, C.; Peng, J.; Du, H.; Zeng, Y.; Ding, M. Oriented conversion of $\gamma$-Valerolactone to gasoline range fuels via integrated catalytic system. Mol. Catal. 2020, 498, 111267. [CrossRef]

71. Huber, G.W.; Iborra, S.; Corma, A. Synthesis of transportation fuels from biomass: Chemistry, catalysts, and engineering. Chem. Rev. 2006, 106, 4044-4098. [CrossRef] [PubMed]

72. Janssen, A.J.; Kremer, F.W.; Baron, J.H.; Muether, M.; Pischinger, S.; Klankermayer, J. Tailor-made fuels from biomass for homogeneous low-temperature diesel combustion. Energy Fuels 2011, 25, 4734-4744. [CrossRef]

73. Bond, J.Q.; Alonso, D.M.; Wang, D.; West, R.M.; Dumesic, J.A. Integrated catalytic conversion of $\gamma$-Valerolactone to liquid alkenes for transportation fuels. Science 2010, 327, 1110-1114. [CrossRef] [PubMed] 
74. Patil, S.K.R.; Heltzel, J.; Lund, C.R.F. Comparison of Structural Features of Humins Formed Catalytically from Glucose, Fructose, and 5-Hydroxymethylfurfuraldehyde. Energy Fuels 2012, 26, 5281-5293. [CrossRef]

75. Patil, S.K.R.; Lund, C.R.F. Formation and growth of humins via aldol addition and condensation during acid-catalyzed conversion of 5-Hydroxymethylfurfural. Energy Fuels 2011, 25, 4745-4755. [CrossRef]

76. Termvidchakorn, C.; Itthibenchapong, V.; Songtawee, S.; Chamnankid, B.; Namuangruk, S.; Faungnawakij, K.; Charinpanitkul, T.; Khunchit, R.; Hansupaluk, N.; Sano, N.; et al. Dehydration of D-xylose to furfural using acid-functionalized MWCNTs catalysts. Adv. Nat. Sci. Nanosci. Nanotechnol. 2017, 8, 035006. [CrossRef]

77. Putro, J.N.; Kurniawan, A.; Soetaredjo, F.E.; Lin, S.-Y.; Ju, Y.-H.; Ismadji, S. Production of gamma-valerolactone from sugarcane bagasse over $\mathrm{TiO}_{2}$-supported platinum and acid-activated bentonite as a co-catalyst. RSC Adv. 2015, 5, 41285-41299. [CrossRef]

78. Metzker, G.; Burtoloso, A.C.B. Conversion of levulinic acid into $\gamma$-valerolactone using $\mathrm{Fe}_{3}(\mathrm{CO})_{12}$ : Mimicking a biorefinery setting by exploiting crude liquors from biomass acid hydrolysis. Chem. Commun. 2015, 51, 14199-14202. [CrossRef]

79. Heeres, H.; Handana, R.; Chunai, D.; Borromeus Rasrendra, C.; Girisuta, B.; Jan Heeres, H. Combined dehydration/(transfer)hydrogenation of C6-sugars (D-glucose and D-fructose) to $\gamma$-valerolactone using ruthenium catalysts. Green Chem. 2009, 11, 1247-1255. [CrossRef]

80. Zhou, H.; Song, J.; Kang, X.; Hu, J.; Yang, Y.; Fan, H.; Meng, Q.; Han, B. One-pot conversion of carbohydrates into gammavalerolactone catalyzed by highly cross-linked ionic liquid polymer and $\mathrm{Co} / \mathrm{TiO}_{2}$. RSC Adv. 2015, 5, 15267-15273. [CrossRef]

81. Wang, T.; He, J.; Zhang, Y. Production of $\gamma$-Valerolactone from one-pot transformation of biomass-derived carbohydrates over chitosan-supported Ruthenium catalyst combined with Zeolite ZSM-5. European J. Org. Chem. 2020, 2020, 1611-1619. [CrossRef]

82. Zhao, W.; Meier, S.; Yang, S.; Riisager, A. Ammonia borane enabled upgrading of biomass derivatives at room temperature. Green Chem. 2020, 22, 5972-5977. [CrossRef]

83. Kim, K.D.; Kim, J.; Teoh, W.Y.; Kim, J.-C.; Huang, J.; Ryoo, R. Cascade reaction engineering on zirconia-supported mesoporous MFI zeolites with tunable Lewis-Brønsted acid sites: A case of the one-pot conversion of furfural to $\gamma$-valerolactone. RSC Adv. 2020, 10, 35318-35328. [CrossRef]

84. Li, X.; Yuan, X.; Xia, G.; Liang, J.; Liu, C.; Wang, Z.; Yang, W. Catalytic production of $\gamma$-valerolactone from xylose over delaminated Zr-Al-SCM-1 zeolite via a cascade process. J. Catal. 2020, 392, 175-185. [CrossRef]

85. Yang, I.-S.; Salama, E.-S.; Kim, J.-O.; Govindwar, S.P.; Kurade, M.B.; Lee, M.; Roh, H.-S.; Jeon, B.-H. Cultivation and harvesting of microalgae in photobioreactor for biodiesel production and simultaneous nutrient removal. Energy Convers. Manag. 2016, 117, 54-62. [CrossRef]

86. Mathimani, T.; Baldinelli, A.; Rajendran, K.; Prabakar, D.; Matheswaran, M.; Pieter van Leeuwen, R.; Pugazhendhi, A. Review on cultivation and thermochemical conversion of microalgae to fuels and chemicals: Process evaluation and knowledge gaps. J. Clean. Prod. 2019, 208, 1053-1064. [CrossRef]

87. McKendry, P. Energy production from biomass (part 1): Overview of biomass. Bioresour. Technol. 2002, 83, 37-46. [CrossRef]

88. Dahiya, A. Bioenergy. Biomass to Biofuels and Waste to Energy; Dahiya, A., Ed.; Elsevier: Amsterdam, The Netherlands, 2020. ISBN 9780128154977.

89. Christoforou, E.; Fokaides, P.A. Advances in Solid Biofuels; Springer: Berlin/Heidelberg, Germany, 2019; Volume PartF1, ISBN 9783030008611. [CrossRef]

90. Karkania, V.; Fanara, E.; Zabaniotou, A. Review of sustainable biomass pellets production-A study for agricultural residues pellets' market in Greece. Renew. Sustain. Energy Rev. 2012, 16, 1426-1436. [CrossRef]

91. Yousuf, A.; Pirozzi, D.; Sannino, F. Lignocellulosic Biomass to Liquid Biofuels; Elsevier: Amsterdam, The Netherlands, 2020. ISBN 9780128159361. [CrossRef]

92. Erdal, S. Gasoline Additives and Public Health. In Encyclopedia of Energy; Elsevier: Amsterdam, The Netherlands, 2004; pp. 821-830. [CrossRef]

93. Drapcho, C.; Nghiem, N.P.; Walker, T.H. Biofuels Engineering Process Technology; Drapcho, C., Nghiem, N.P., Walker, T.H., Eds.; McGRAW-HILL, Inc.: New York, NY, USA, 2020. ISBN 9781260457650.

94. Du, X.-L.; Bi, Q.-Y.; Liu, Y.-M.; Cao, Y.; He, H.-Y.; Fan, K.-N. Tunable copper-catalyzed chemoselective hydrogenolysis of biomass-derived $\gamma$-valerolactone into 1,4-pentanediol or 2-methyltetrahydrofuran. Green Chem. 2012, 14, 935-939. [CrossRef]

95. Lange, J.-P.; Price, R.; Ayoub, P.M.; Louis, J.; Petrus, L.; Clarke, L.; Gosselink, H. Valeric biofuels: A platform of cellulosic transportation fuels. Angew. Chem. Int. Ed. 2010, 49, 4479-4483. [CrossRef]

96. Tang, X.; Sun, Y.; Zeng, X.; Lei, T.; Li, H.; Lin, L. $\gamma$-Valerolactone-An excellent solvent and a promising building block. In Biomass, Biofuels, Biochemicals; Saravanamurugan, S., Li, H., Riisager, A., Pandey, A., Eds.; Elsevier: Amsterdam, The Netherlands, 2020; pp. 199-226. ISBN 9780444643070. [CrossRef]

97. Christoforou, E.A.; Fokaides, P.A. Life cycle assessment (LCA) of olive husk torrefaction. Renew. Energy 2016, 90, 257-266. [CrossRef]

98. Peksa-Blanchard, M.; Dolzan, P.; Grassi, A.; Heinimo, J.; Junginger, M.; Ranta, T.; Walter, A. Global Wood Pellets Markets and Industry: Policy Drivers, Market Status and Raw Material Potential; IEA Bioenergy: Dublin, Ireland, 2007.

99. Buckner, C.U.S. Fuel Ethanol Production Capacity Continues to Increase-Today in Energy-U.S. Energy Information Administration (EIA). Available online: https:/ / www.eia.gov/todayinenergy/detail.php?id=36774 (accessed on 27 December 2020).

100. Zhang, Z.; Lis, M. Modeling green energy development based on sustainable economic growth in China. Sustainability 2020, 12, 1368. [CrossRef] 
101. Mohanty, S.K.; Swain, M.R. Bioethanol Production from Corn and Wheat: Food, Fuel, and Future. In Bioethanol Production from Food Crops; Elsevier: Amsterdam, The Netherlands, 2019; pp. 45-59. [CrossRef]

102. Paulino de Souza, J.; Dias do Prado, C.; Eleutherio, E.C.A.; Bonatto, D.; Malavazi, I.; Ferreira da Cunha, A. Improvement of Brazilian bioethanol production-Challenges and perspectives on the identification and genetic modification of new strains of Saccharomyces cerevisiae yeasts isolated during ethanol process. Fungal Biol. 2018, 122, 583-591. [CrossRef] [PubMed]

103. Ayodele, B.V.; Alsaffar, M.A.; Mustapa, S.I. An overview of integration opportunities for sustainable bioethanol production from first- and second-generation sugar-based feedstocks. J. Clean. Prod. 2020, 245, 118857. [CrossRef]

104. Joelsson, E.; Erdei, B.; Galbe, M.; Wallberg, O. Techno-economic evaluation of integrated first- and second-generation ethanol production from grain and straw. Biotechnol. Biofuels 2016, 9, 1. [CrossRef]

105. Ferreira, J.A.; Brancoli, P.; Agnihotri, S.; Bolton, K.; Taherzadeh, M.J. A review of integration strategies of lignocelluloses and other wastes in 1st generation bioethanol processes. Process Biochem. 2018, 75, 173-186. [CrossRef]

106. Kim, J.; Han, J. Simulation study of a strategy to produce gamma-valerolactone from ethyl levulinate. Energy 2018, 163, 986-991. [CrossRef]

107. Han, J. Process design and techno-economic evaluation for catalytic production of cellulosic $\gamma$-Valerolactone using lignin derived propyl guaiacol. J. Ind. Eng. Chem. 2017, 52, 218-223. [CrossRef]

108. Byun, J.; Han, J. Catalytic conversion of corn stover for (gamma)-valerolactone production by two different solvent strategies: Techno-economic assessment. Energy 2019, 175, 546-553. [CrossRef]

109. Cardona, C.A.; Sánchez, Ó.J. Fuel ethanol production: Process design trends and integration opportunities. Bioresour. Technol. 2007, 98, 2415-2457. [CrossRef]

110. Oliveira, C.M.; Cruz, A.J.G.; Costa, C.B.B. Improving second generation bioethanol production in sugarcane biorefineries through energy integration. Appl. Therm. Eng. 2016, 109, 819-827. [CrossRef]

111. Oliveira, C.M.; Pavão, L.V.; Ravagnani, M.A.S.S.; Cruz, A.J.G.; Costa, C.B.B. Process integration of a multiperiod sugarcane biorefinery. Appl. Energy 2018, 213, 520-539. [CrossRef]

112. Dias, M.O.S.; Modesto, M.; Ensinas, A.V.; Nebra, S.A.; Filho, R.M.; Rossell, C.E.V. Improving bioethanol production from sugarcane: Evaluation of distillation, thermal integration and cogeneration systems. Energy 2011, 36, 3691-3703. [CrossRef]

113. Grossmann, I.E.; Martín, M. Energy and water optimization in biofuel plants. Chin. J. Chem. Eng. 2010, 18, 914-922. [CrossRef]

114. Silva Lora, E.E.; Escobar Palacio, J.C.; Rocha, M.H.; Grillo Renó, M.L.; Venturini, O.J.; Almazán del Olmo, O. Issues to consider, existing tools and constraints in biofuels sustainability assessments. Energy 2011, 36, 2097-2110. [CrossRef]

115. Laschi, A.; Marchi, E.; González-García, S. Environmental performance of wood pellets' production through life cycle analysis. Energy 2016, 103, 469-480. [CrossRef]

116. Borrion, A.L.; McManus, M.C.; Hammond, G.P. Environmental life cycle assessment of lignocellulosic conversion to ethanol: A review. Renew. Sustain. Energy Rev. 2012, 16, 4638-4650. [CrossRef]

117. Clauser, N.M.; Felissia, F.F.; Area, M.C.; Vallejos, M.E. A framework for the design and analysis of integrated multi-product biorefineries from agricultural and forestry wastes. Renew. Sustain. Energy Rev. 2020, in press.

118. Clauser, N.M.; Gutiérrez, S.; Area, M.C.; Felissia, F.E.; Vallejos, M.E. Techno-economic assessment of carboxylic acids, furfural, and pellet production in a pine sawdust biorefinery. Biofuels Bioprod. Biorefin. 2018, 12, 997-1012. [CrossRef]

119. Argus. Argus Biomass Markets; Argus: London, UK, 2018.

120. Clauser, N.M.; Gutiérrez, S.; Area, M.C.; Felissia, F.E.; Vallejos, M.E. Alternatives of small-scale biorefineries for the integrated production of xylitol from sugarcane bagasse. J. Renew. Mater. 2018, 6, 139-151. [CrossRef]

121. Sahoo, K.; Bilek, E.; Bergman, R.; Mani, S. Techno-economic analysis of producing solid biofuels and biochar from forest residues using portable systems. Appl. Energy 2019, 235, 578-590. [CrossRef]

122. Grand View Research Ethanol Market Size, Share \& Trends Report, 2020-2027. Available online: https://www.grandviewresearc h.com/industry-analysis/ethanol-market (accessed on 20 September 2020).

123. CISION PR Newswire Ethanol Market Size Worth $\$ 129.36$ Billion by 2027 I CAGR 4.8\%: Grand View Research, Inc. Available online: https: / / www.prnewswire.com/news-releases / ethanol-market-size-worth-129-36-billion-by-2027--cagr-4-8-grand-vi ew-research-inc-301081641.html (accessed on 20 September 2020).

124. Kohler, M. Economic Assessment of Ethanol Production. In Ethanol; Elsevier: Amsterdam, The Netherlands, 2019 ; pp. 505-521. ISBN 9780128114582. [CrossRef]

125. Zhao, X.; Li, S.; Wu, R.; Liu, D. Organosolv fractionating pre-treatment of lignocellulosic biomass for efficient enzymatic saccharification: Chemistry, kinetics, and substrate structures. Biofuels Bioprod. Biorefin. 2017, 11, 567-590. [CrossRef]

126. Ponnusamy, V.K.; Nguyen, D.D.; Dharmaraja, J.; Shobana, S.; Banu, J.R.; Saratale, R.G.; Chang, S.W.; Kumar, G. A review on lignin structure, pretreatments, fermentation reactions and biorefinery potential. Bioresour. Technol. 2019, 271, 462-472. [CrossRef] [PubMed]

127. Den, W.; Sharma, V.K.; Lee, M.; Nadadur, G.; Varma, R.S. Lignocellulosic biomass transformations via greener oxidative pretreatment processes: Access to energy and value-added chemicals. Front. Chem. 2018, 6, 141. [CrossRef]

128. Matsakas, L.; Raghavendran, V.; Yakimenko, O.; Persson, G.; Olsson, E.; Rova, U.; Olsson, L.; Christakopoulos, P. Lignin-first biomass fractionation using a hybrid organosolv-Steam explosion pretreatment technology improves the saccharification and fermentability of spruce biomass. Bioresour. Technol. 2019, 273, 521-528. [CrossRef]

129. Wilson, K.; Lee, A.F. Catalyst design for biorefining. Philos. Trans. R. Soc. A Math. Phys. Eng. Sci. 2016, 374, 20150081. [CrossRef] 
130. Rinaldi, R.; Schüth, F. Acid hydrolysis of cellulose as the entry point into biorefinery schemes. ChemSusChem 2009, 2, $1096-1107$. [CrossRef]

131. Islam, M.K.; Wang, H.; Rehman, S.; Dong, C.; Hsu, H.Y.; Lin, C.S.K.; Leu, S.Y. Sustainability metrics of pretreatment processes in a waste derived lignocellulosic biomass biorefinery. Bioresour. Technol. 2020, 298, 122558. [CrossRef]

132. Mountraki, A.; Tsakalova, M.; Panteli, A.; Papoutsi, A.I.; Kokossis, A.C. Integrated Waste Management in Multiproduct Biorefineries: Systems Optimization and Analysis of a Real-Life Industrial Plant. Ind. Eng. Chem. Res. 2016, 55, 3478-3492. [CrossRef]

133. Chow, C.-F.; Ho, P.-Y.; Wong, W.-L.; Lu, Y.-J.; Tang, Q.; Gong, C.-B. Catalyst displacement assay: A supramolecular approach for the design of smart latent catalysts for pollutant monitoring and removal. Chem. Sci. 2017, 8, 3812-3820. [CrossRef]

134. Covinich, L.G.; Massa, P.; Fenoglio, R.J.; Area, M.C. Oxidation of hazardous compounds by heterogeneous catalysis based on $\mathrm{Cu} / \mathrm{Al}_{2} \mathrm{O}_{3}$ system in fenton type reactions. Crit. Rev. Environ. Sci. Technol. 2016, 46, 1745-1781. [CrossRef]

135. Cherubini, F.; Ulgiati, S. Crop residues as raw materials for biorefinery systems-A LCA case study. Appl. Energy 2010, 87, 47-57. [CrossRef] 